\title{
El legado fotográfico y planimétrico de Julio Martínez Santa-Olalla (1953-1962).
}

\author{
JUan BLÁNQUEZ (UAM) ${ }^{1}$ \\ Lourdes ROLDÁN (UAM)
}

De todos los homenajes que se puede rendir a un Maestro, no olvidarlo es uno de los más sinceros. ¿Anónimo?

\section{Resumen}

El archivo fotográfico de Julio Martínez Santa-Olalla, con más de 400 imágenes clasificadas por el momento, nos permiten conocer con exactitud las excavaciones realizadas por este investigador en el yacimiento de Carteia (San Roque, Cádiz). Éstas las desarrolló, no sólo en las termas, donde llegó a excavar en más de dos tercios de la planta que hoy se visita, también en diferentes puntos del circuito murario romano y en el teatro. Especialmente interesantes, por sus posibilidades de estudio, han sido las imágenes relacionadas con sus excavaciones en la denominada "necrópolis de las termas", hoy por desgracia desaparecida casi en su práctica totalidad; en la también "necrópolis de la Torre del Rocadillo", que hoy tampoco se conserva y, por último, en la finca denominada "Huerto del Gallo", lugar éste donde había aparecido en 1840 un tablero de mármol decorado con guirnaldas y bucráneo. Esta importante pieza marmórea materializa el logotipo de la nueva sede del Museo Municipal de San Roque.

Palabras clave: Carteia, Fotografía arqueológica, Círculo del Estrecho, Martínez Santa-Olalla, Historiografía.

\section{Summary}

Photographic archive of Martínez Santa-Olalla, with over 400 images classified to date, provides precise information about the excavations he conducted at the site of Carteia (San Roque, Cádiz). These focused not only on the baths, where he excavated over two thirds of the area now open to visitors, but also on different segments of the Roman walls and the theatre. Of particular interest in terms of the results obtained were his excavations of the "bath necropolis", which unfortunately has now disappeared almost completely, the "Rocadillo Tower necropolis", which has not survived either, and the estate known as "Huerto del Gallo", where a marble slab decorated with festoons and a bucranium - currently one of the most important exhibits at the Municipal Museum of San Roque.

Keywords: Carteia, Archaeological photography, Straits of Gibraltar, Martínez Santa-Olalla, Historiography.

1 juan.blanquez@uam.es Departamento de Prehistoria y Arqueología. Universidad Autónoma de Madrid.
2 lourdes.roldan@uam.es Departamento de Historia y Teoría del Arte. Universidad Autónoma de Madrid. 


\section{A Modo de InTRoducción}

Como es sabido, la actual bahía de Algeciras y su población distribuida por todo el entorno de su ensenada constituyen -todavía hoy- testimonio claro del importante proceso cultural que en aquella ha tenido lugar a lo largo de casi tres milenios. Hablamos de la implantación y posterior desarrollo del horizonte urbano y llamamos la atención de cómo, en el mismo, la antigua ciudad de Carteia (San Roque, Cádiz) y su territorio fueron protagonistas materiales de aquel proceso a lo largo de más de 18 siglos.

Llamar la atención sobre esta evidencia hoy nos puede parecer algo evidente, pero conviene recordar que se encuentra apoyado sobre argumentaciones científicas sólidas, fruto de un largo periodo de investigación de más de 17 años, y no sobre la emoción y los sentimientos. En efecto, primero, casi de manera exclusiva, a través de las Fuentes Clásicas, más tarde por hallazgos fortuitos -en especial de carácter numismático y epigráfico- así como por referencias y descripciones de vestigios monumentales el conocimiento de tan importante yacimiento arqueológico no se perdió en la memoria histórica de los hombres. Pero fue a partir de la segunda mitad del pasado siglo XX cuando, gracias a la investigación arqueológica, se produjo un verdadero punto de inflexión en favor de su conocimiento.
El tradicional interés científico despertado por la ciudad de Carteia y su entorno se apoya y explica en una suma de circunstancias de muy variadas características. Por un lado, la imprescindible valoración-análisis del área geográfica en la que se asentó esta ciudad antigua; por otro, su propia evolución histórica, de clara trascendencia mucho más allá de su recinto amurallado, desde la fundación como factoría fenicia a mediados del siglo VII a.C., en lo que hoy valoramos como "Carteia La Vieja" y la posterior próspera ciudad púnica, hasta su transformación en Colonia Libertinorum Carteia, el haber llegado a ser -muy probablemente- cabeza episcopal en época tardoantigua $\mathrm{y}$, por último, como fortaleza avanzada de la ciudad meriní de al-Yacirat, la actual Algeciras.

Tras medio siglo de excavaciones en su espacio urbano y sin entrar ahora en la mayor o menor relevancia de los trabajos acometidos por los sucesivos equipos de arqueólogos -no es lugar éste el adecuado ni el tema que nos ocupa-, en la última década de investigaciones ha quedado ya evidente la necesidad de extender los estudios arqueológicos a su entorno: a los espacios periurbano y territorial (FIGURA 1). Por ello, desde el año 2006 y coincidiendo con un nuevo sexenio de investigaciones en el yacimiento -Proyecto Carteia. Fase II (2006-2013) auspiciado por la

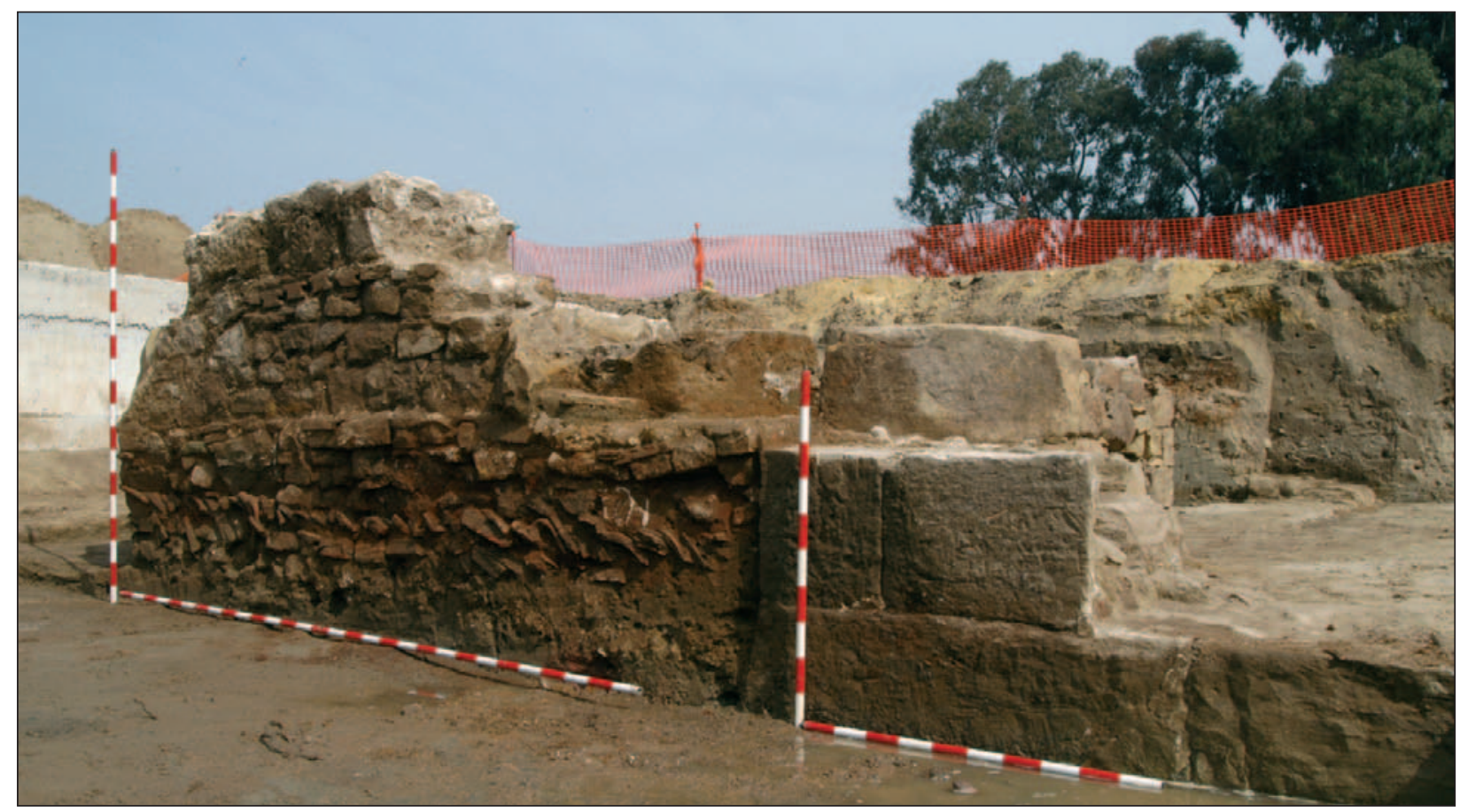

Figura 1. Vista general del embarcadero de "Villa Victoria", en Puente Mayorga (San Roque, Cádiz), barriada alfarera de Carteia. En la actualidad montado en la nueva sede del Museo Municipal de la ciudad (2005). 
Junta de Andalucía- se ha iniciado una nueva línea de trabajo en torno a los Estudios Historiográficos, Paleotopográficos, Paleaombientales y de Cartografía Antigua centrados, como es fácil imaginar, en el Campo de Gibraltar. Se tratan, pues, de estudios independientes, si bien complementarios con los tradicionales de corte directamente arqueológico al estar aquellos atentos a la evolución del "paisaje cultural" de la Bahía de Algeciras en la Antigüedad. Esta nueva línea de trabajo, dirigidos también por los autores de este texto-homenaje, cuenta hoy con el patrocinio de la refinería Gibraltar-San Roque, de CEPSA.

\section{LA INVESTIGACIÓN ARQUEOLÓGICA}

Las investigaciones arqueológicas llevadas a cabo en Carteia a lo largo de la segunda mitad del s. XX por tres sucesivos equipos de trabajo (19531985) es indudable que mejoraron el conocimiento material de la ciudad y que ello conllevó incuestionables aportaciones científicas. No obstante, en conjunto, diríamos hoy que se podrían caracterizar como excesivamente parciales, pues estuvieron prácticamente centradas en el espacio urbano. De igual manera, fueron muy desiguales, en cuanto al rigor con que fueron acometidas.

Aquellos trabajos, fundamentalmente los llevados a cabo por el equipo de Woods, permitieron desmontar de manera definitiva la tradicional identificación de esta ciudad con la mítica Tarteso, si bien aportaron suficientes datos como para empezar a valorar su importante pasado fenopúnico. En este sentido, aun a pesar del escaso desarrollo de la arqueología de este periodo histórico en nuestro país hasta bien entrados los años 60, ya Julio Martínez Santa-Olalla -su primer excavador- había avanzado que "fenicios y cartagineses habían aportado elementos mediterráneos a las zonas costeras meridionales y levantinas, desde donde los colonos púnicos, con su profunda penetración en el país a partir de los centros urbanos costeros - caso de Carteia-se habrían encargado de propagar dichos influjos a partir del 350 a.C." (Prados, 2011). Décadas después de aquellas primeras valoraciones, las investigaciones arqueológicas acometidas desde 1994 por un equipo de la Universidad Autónoma de Madrid han aportado novedosa documentación acerca de la esta "presencia púnica" en la ciudad de Carteia (Blánquez y Roldán, 2003; Blánquez et alii, 2007; Blánquez y Roldán, 2009).
El análisis global con que, metodológicamente hablando, hoy día se acometen las investigaciones en el asentamiento urbano de Carteia también ha permitido aportar interesantes datos acerca de las transformaciones producidas en las comunidades hispanas a la llegada del mundo romano, es decir, lo que bien podríamos llamar "periodo tardopúnico" que, indudablemente, existió en el sur y levante peninsular tras el final de la II Guerra Púnica. Así, pues, el estudio de la Bahía de Algeciras y, con ella, de la ciudad y el territorio de Carteia se vienen a sumar a la moderna investigación que ha puesto de relieve el más que notable nivel urbano de la Península Ibérica previo a la llegada de Roma y que hunde sus raíces en la discutida cultura tartésica y en la presencia "colonial" fenicia y griega. Ejemplos notables de aquel nivel urbano habrían sido, entre otros, CartHadasht (Cartagena) o Tossal de Manises (Alicante)... que habrían preparado la acción de Roma "quien perpetuó y consolidó una monumentalización arquitectónica con la incorporaron de elementos propios de la ciudad romana, en general, pero con notables especificidades hispanas" (Bendala, 2011).

Carteia fue, durante siglos, un hito fundamental en el culturalmente denominado "Circulo del Estrecho", con intensas y mantenidas en el tiempo relaciones económicas y culturales entre sus dos orillas (FIGURA 2). Ello está bien documentado, sobre todo, en las etapas feniciopúnica y romana, tal y como recoge la bibliografía (Morrell, 2006; Gozalbes, 2006), fundamentalmente a través de los estudios ceramológicos, de ánforas y, en general, de sus recursos económi$\cos$ (Cheddad, 2008; Hassini, 2006). En este sentido, es especialmente significativo lo concerniente con su actividad pesquera y, derivada de ella, la de la industria salazonera (Lagostena, 2001; Etienne y Mayet, 2002; Arévalo y Bernal, 2007; Bernal, 2011a).

Pero los trabajos arqueológicos llevados a cabo en Carteia en los últimos 18 años, además de ilustrar de manera evidente los poco estudiados periodos púnico y romano republicano e imperial, también han estado interesados en documentar otras etapas, asimismo, de escaso conocimiento como, por ejemplo, la Tardía Antigüedad, hasta el punto de que hoy Carteia está considerada -junto con la ciudad de Traducta (Villa Vieja de Algeciras- como los dos núcleos urbanos activos 


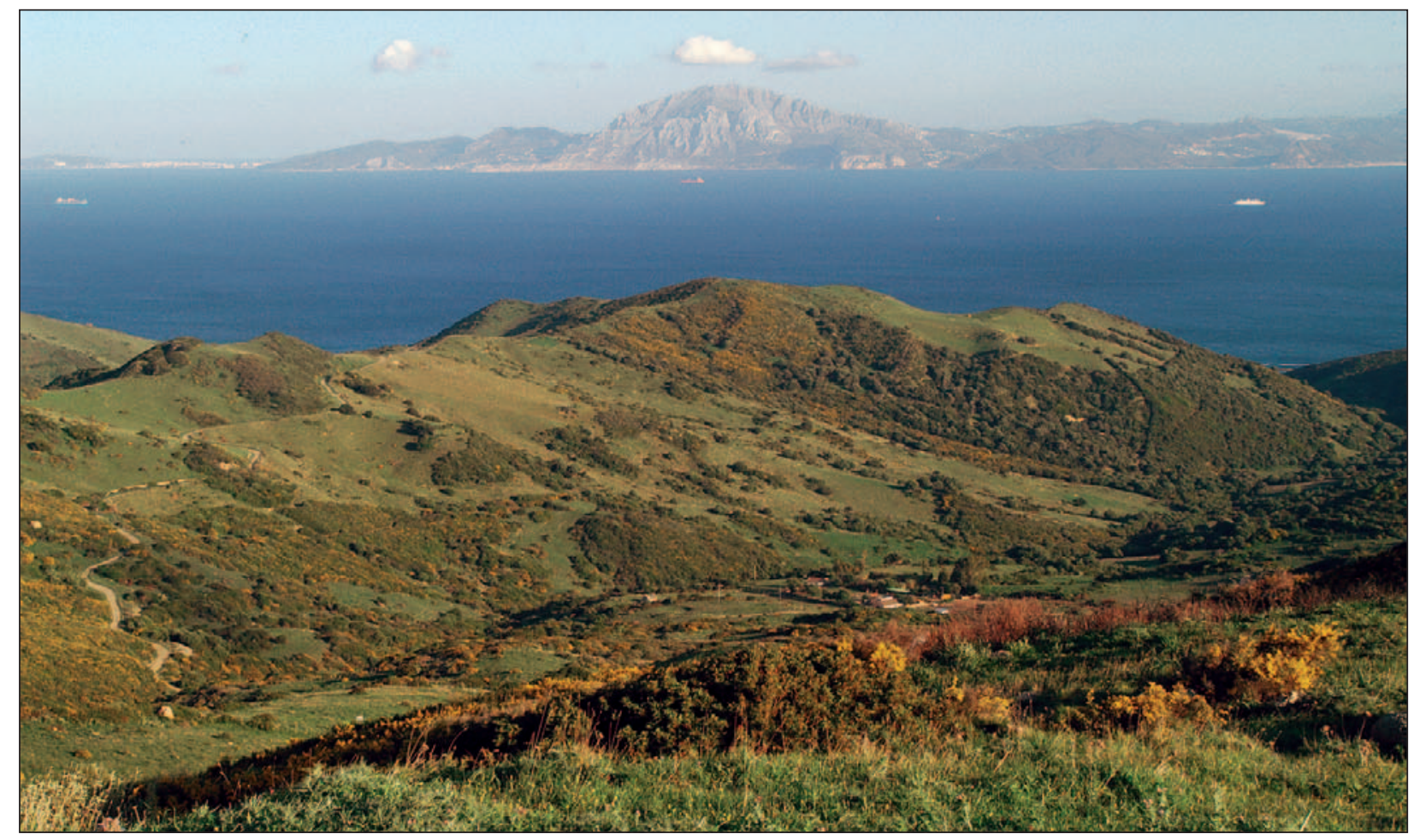

Figura 2. Vista de África desde "el mirador del Estrecho" donde la distancia es de, tan sólo, 15 km.

(C) Proyecto Carteia de la UAM (2010).

en la Bahía de Algeciras (Bernal, 2004; Bernal, 2011b). Ello, por no hablar de la posterior época almohade y meriní (Martínez Lillo, 2006).

Sin embargo, nuestra intención en este primer homenaje al profesor Manuel Bendala no es reflejar las más recientes investigaciones en Carteia, ya reseñadas en otros ámbitos (Roldán et alii, 2006), ni glosar nuestro primeros pasos en este yacimiento recorridos, por cierto, con el citado profesor... más bien, dedicarle con gratitud una "nueva página" dentro de esta línea de estudios recorrida por nosotros ya con mayor protagonismo. Nos referimos a la relacionada con los estudios historiográficos a través de legados documentales directamente relacionados con sus antiguos excavadores. En concreto, en esta ocasión, con el de Julio Martínez Santa-Olalla gracias al "descubrimiento", hace pocos años, de parte de su personal archivo fotográfico directamente relacionado con sus excavaciones en la ciudad de Carteia y que, por amabilidad de la anterior directora del Museo Arqueológico Nacional -Rubí Sanz Gamo- acometemos hoy su estudio (Roldán et alii 2011a, XVII). Tiene, además, el valor añadido el que de aquel periodo de trabajos arqueológicos comprendido entre 1953 y 1962, prácticamente, nada fue publicado.

\section{CARTEIA Y EL PATRIMONIO ARQUEOLÓGICO GADITANO A PRINCIPIOS DEL SIGLO XX}

La importancia del yacimiento de Carteia en el panorama patrimonial gaditano y, en general, español ha estado apoyado, entre otras cuestiones, por su incuestionable carácter monumental, así como por la visibilidad física de los restos materiales excavados a lo largo de más de seis décadas. Sin embargo, tal y como ha quedado puesto de manifiesto en anteriores publicaciones (Roldán y Blánquez, 2011 a y b), exceptuando puntuales aportaciones, la intensidad de los trabajos de campo, de manera tradicional, no han venido acompañados de una pareja proporción de publicaciones científicas hasta, prácticamente, los años 90. Salvo la interesante Memoria de excavaciones de Woods y su equipo de arqueólogos sevillanos (Woods et alii, 1967) y la más técnica de su posterior excavador, Francisco Presedo (Presedo et alii, 1982) poco más vio la luz de todo lo sacado.

De forma independiente, si bien con notable posterioridad, se han publicado sucesivos trabajos monográficos relativos al ámbito de la Bahía (Bernal, 1998; Idem y Lorenzo, 2002; JiménezCamino y Tomassetti, 2005; Roldán et alii, 2006; 
Jiménez Vialás, 2011, entre otros), así como colaboraciones puntuales en la interesante revista Almoraima, tradicional órgano de expresión intelectual, escrito, de los estudios -sobre todo históricos- del Campo de Gibraltar. En esta misma línea, pero con mayor vinculación a los trabajos arqueológicos, habría que destacar la revista Caetaria, editada por la Fundación Municipal de Cultura «José Luis Cano», dependiente del Ayuntamiento de Algeciras. Aun con todo, la actual Bahía de Algeciras -antes de Gibraltarsigue careciendo, todavía hoy, de adecuados -podíamos decir también que completos- estudios arqueológicos de conjunto. Dicha carencia tiene mayor importancia de lo habitual dentro del panorama arqueológico español si tenemos en cuenta, además, la más que notable transformación topográfica y poblacional que ha experimentado el arco de la Bahía a partir de los años 60 del pasado sigloXX a raíz de su fuerte industrialización y, muy posiblemente, también por la falta de una adecuada política de ordenación urbana (Arteaga et alii, 1987; Jiménez-Camino y Tomasetti, 2005; Artega y González, 2006).

Pero por contradictorio que parezca, si buscamos "los primeros pasos" de los estudios arqueológicos en la bahía, sin necesidad de ser exhaustivos, podríamos remontarnos a inicios del pasado siglo XX con una obra que marcó "un antes y un después" en el conocimiento del patrimonio algecireño, en particular, y gaditano en general. Nos estamos refiriendo a la publicación de Enrique Romero de Torres con su Catálogo Monumental de España. Provincia de Cádiz (1908-1909) (FIGURA 3) que, como el propio autor relata, fue "elaborado a propuesta de la Comisión mixta de las Academias de la Historia y de Bellas Artes de San Fernando (...) por Real Orden del Ministerio de Instrucción pública y Bellas Artes, de 27 de mayo de 1907, para catalogar la riqueza artística y monumental de la provincia de Cádiz" (Romero de Torres, 1934, V).

Considerado por él mismo, como el "ensayo de un catálogo de los Monumentos Históricos y Artísticos; como una breve reseña o compendio de toda la riqueza artístico-arqueológica..." quiso ser una recopilación, ordenada con criterio cronológico, destinada a facilitar su estudio "por aquellas personas especializadas en los distintos ramos de la Arqueología y del Arte". De acuerdo con las pautas dadas para la realización de toda la serie de

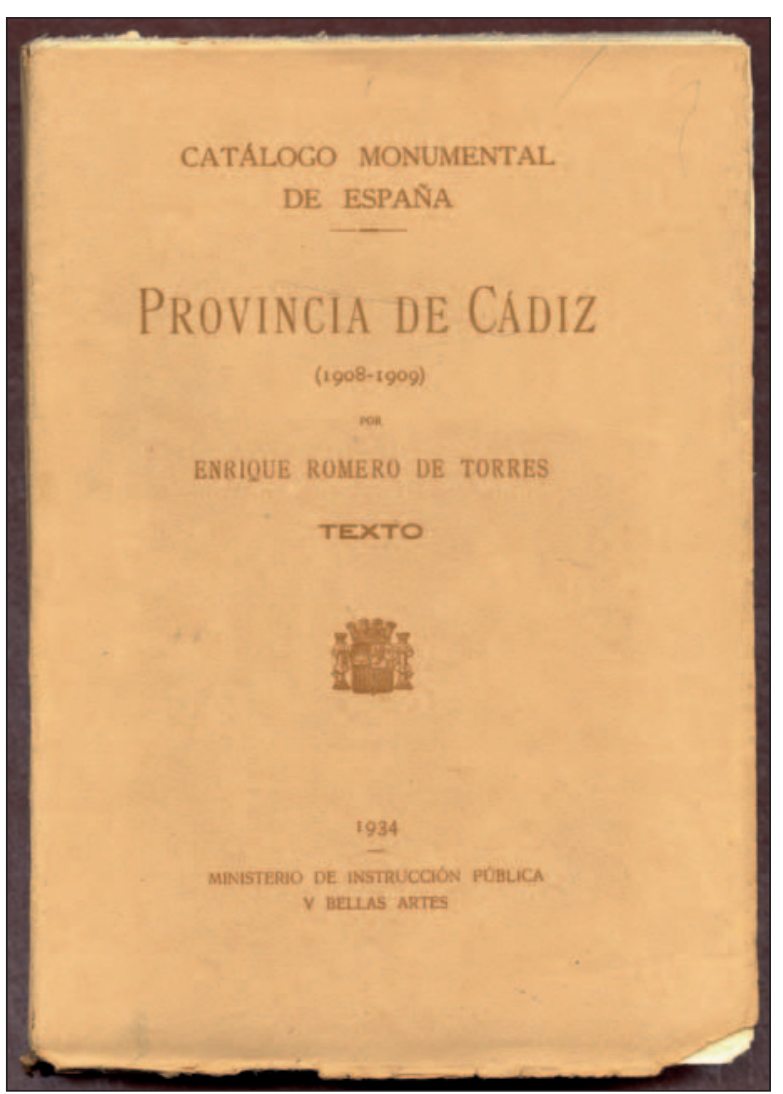

Figura 3. Catálogo Monumental de España. Provincia de Cádiz. E. Romero de Torres (1934). (C) Universidad Autónoma de Madrid, CVFA.

los conocidos Catálogos Monumentales (http://biblioteca.cchs.csic.es/digitalizacion_tnt/) se llevó a cabo acompañado de abundante documentación gráfica "de capital importancia en esta clase de trabajos". El Catálogo quedó estructurado en tres grandes bloques: los principales monumentos prehistóricos de la provincia; la ciudad de Cádiz y, por último, los pueblos de la provincia ordenados por partidos judiciales.

El Catálogo Monumental de España. Provincia de Cádiz (1908-1909) se terminó en 1909 pero, muy propio de este país, quedó guardado en la Dirección de Bellas Artes... durante 20 años. Con posterioridad, una nueva Comisión compuesta por miembros de las Reales Academias de la Historia y de Bellas Artes de San Fernando asumió el encargo de publicar una selección de aquellos Catálogos hasta entonces redactados y, entre ellos, el de la provincia de Cádiz. Así, por Real Orden de 14 de enero de 1928, quedó aprobada su publicación por parte de la Dirección General del Instituto Geográfico y Catastral pero, aun con todo, tuvieron que pasar ocho años más hasta que, en 1934, el libro vio la luz. 


\section{El CATÁlogo MONUMENTAl DE LA} Provincia de Cádiz y Carteia

De la antigua ciudad de Carteia -Carteya según el Itinerario de Antonino- el citado Catálogo Monumental... indica de manera precisa su ubicación en el, conservado hasta los años 80 del pasado siglo, Cortijo del Rocadillo. También apunta la presencia de "monedas, lápidas y otros objetos y ruinas que todavía sobresalen a flor de tierra en los fértiles campos del Rocadillo" (Romero de Torres, 1934, 223), fundamentando aquella valoración en un anterior trabajo suyo publicado en el Boletín de la Real Academia de la Historia (Romero de Torres, 1909: 247 y ss.). Del yacimiento, tan sólo, citó la «ruina» que, cercana al Cortijo del Rocadillo, era conocida por la tradición como un «baptisterio». También recogió la existencia de un sarcófago procedente de una de sus necrópolis -el Huerto del Gallo- y de un bajorrelieve tallado en mármol (FIGURA 4) que, a principios de siglo se encontraba emplazado en el descansillo de la escalera de subida a la primera planta del antiguo Ayuntamiento de San Roque. Poco más.

\section{LAS PRIMERAS EXCAVACIONES EN CARTEIA}

A tenor de lo que hoy sabemos las primeras excavaciones en el yacimiento de Carteia se remontan a 1814, realizadas por el almirante inglés Heming. El conocimiento de las mismas ha llegado hasta nosotros gracias al historiador Montero el almirante Heming que mandaba en la escuadra inglesa del Mediterráneo por los años de 1814, durante su estancia en Gibraltar, mandó practicar con licencia de nuestras autoridades grandes excavaciones y sacó muchas preciosidades en estatuas de mármol y bronce, medallas y otros objetos que se llevó a Londres (Montero, 1860: 76).

Posteriormente, ya en 1928, se conservan nueva noticias acerca de trabajos arqueológicos en Carteia pero, no tanto dentro de la urbe sino en su entorno periurbano, en el hoy desaparecido Huerto del Gallo. Se refieren a una finca extramuros, al este de la antigua ciudad, por aquel entonces propiedad de D. Evaristo Ramos. Allí se había descubierto un año antes el famoso «sarcófago paleocristiano» a tenor de sus aparentes decoraciones iconográficas

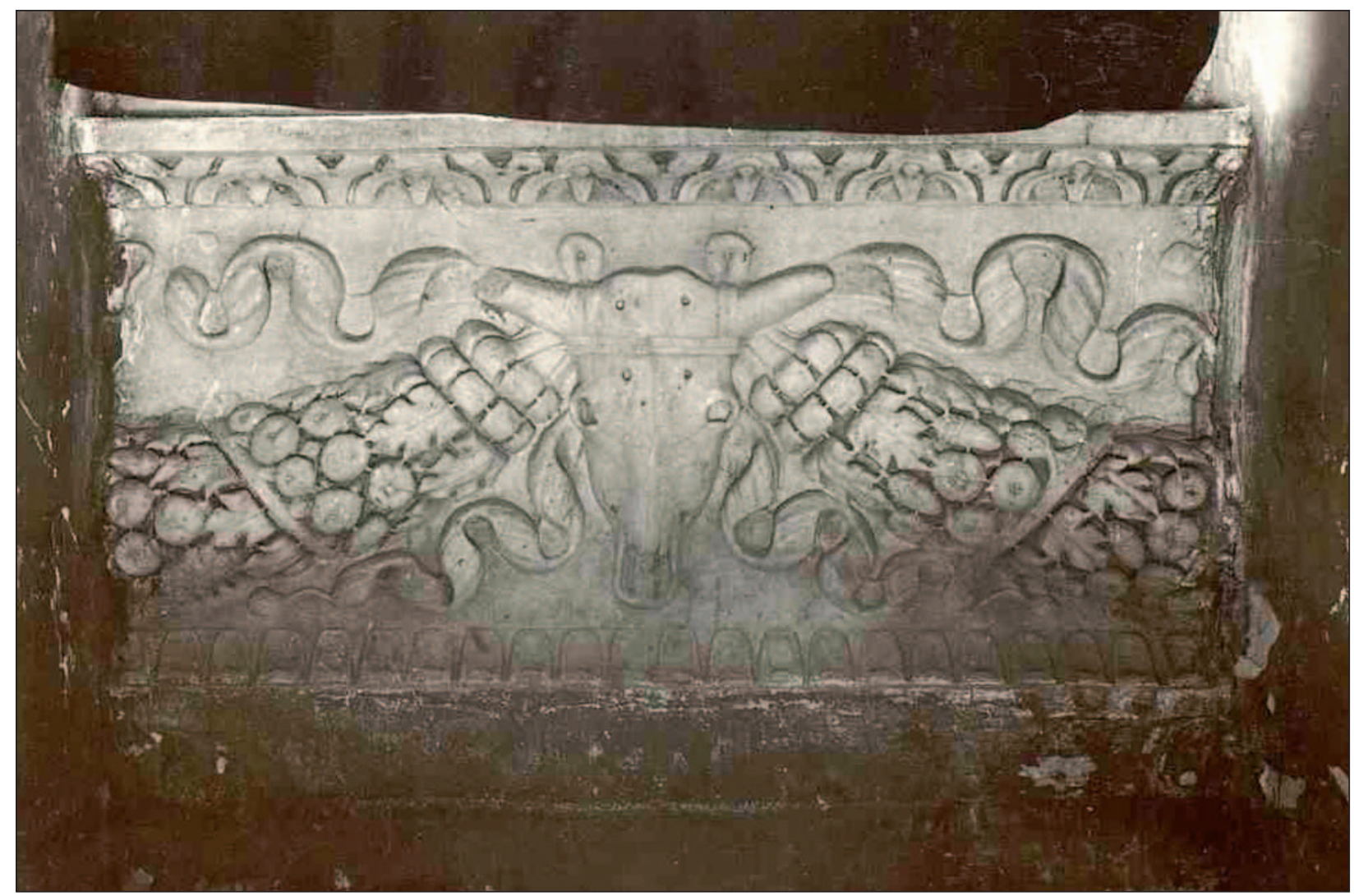

Figura 4. Relieve marmóreo de la necrópolis del "Huerto del Gallo", aparecido en 1848, cuando estaba depositado en la escalera de acceso a la primera planta del antiguo consistorio de San Roque. Entre 1908 y 1909. 


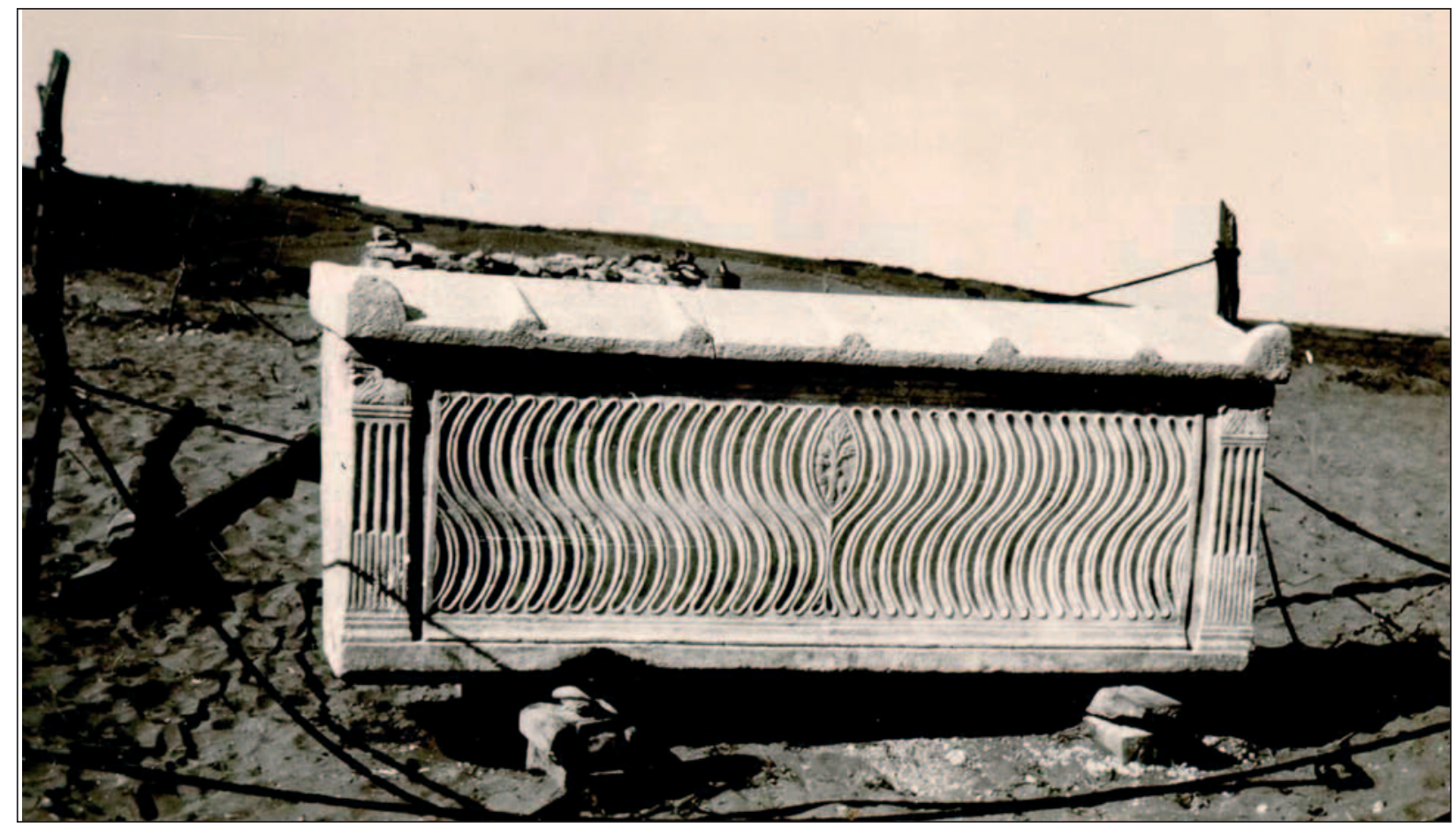

Figura 5. Sarcófago del "Huerto del Gallo", en su lugar de aparición. (C) Sevilla A.G.A., Fondo J. Bonsor, Consejería de Cultura, Sevilla. Negativo nº 0421 (entre 1927 y 1930).

(FIGURA 5) aunque, con posterioridad, una vez bien estudiado, fue fechado por paralelos estilísticos y por la representación de su orla considerado de temática pagana como propio de comienzos del s. IV (Rodríguez Oliva, 2001: 118-120).

\section{Julio Martínez Santa-Olalla y El INI- CIO DE LAS EXCAVACIONES EN CARTEIA A LA LUZ DE SU LEGADO DOCUMENTAL (1953- 1962).}

Con Julio Martínez Santa-Olalla, como decíamos, se produjo una inflexión en el conocimiento de la ciudad de Carteia con el inicio de excavaciones ya sistemáticas y con una metodología que, salvando los años, se debe considerar científica (FIGURA 6). Sus trabajos arqueológicos en el yacimiento se llevaron a cabo a lo largo de una década, entre 1953 y 1962 y, si bien algunos documentos apuntan la posibilidad de haberlos iniciado antes -en 1949- no tenemos seguridad total de ello.

Sus trabajos en Carteia contaron siempre con la ayuda de Bernardo Sáez, su colaborador más querido y como consecuencia de los mismos, hizo posible el que la comunidad científica española tomara conciencia de la importancia de este yacimiento. Desde entonces y salvo pequeños interva-

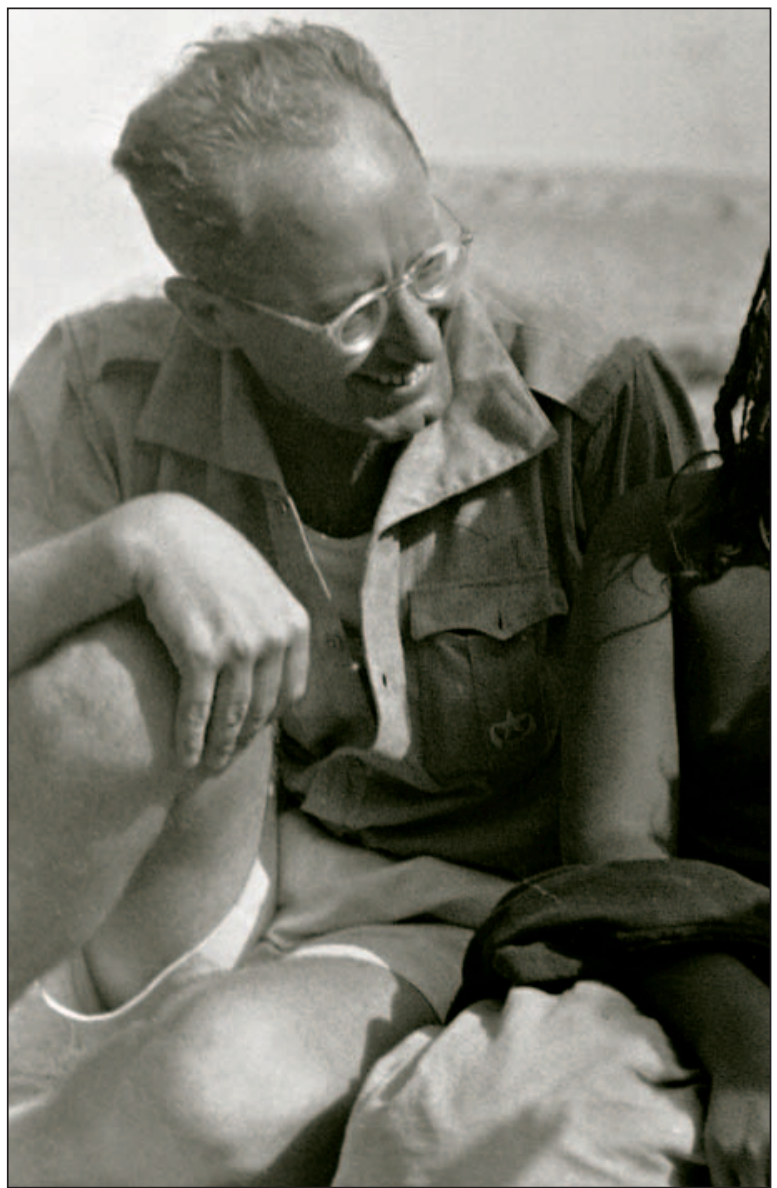

Figura 6. J. Martínez Santa-Olalla en la Expedición Paletnológica al Sahara Español. (C) Proyecto Carteia de la UAM. Legado J. Mtnez. Santa-Olalla (1943). 
los, Carteia no ha dejado de ser excavada hasta nuestros días. Desde su privilegiada posición política a favor del Régimen la actividad arqueológica de Santa-Olalla consiguió, además, el apoyo de instituciones del Campo de Gibraltar y, como consecuencia de ello sus excavaciones generaron una notable colección de piezas que, todavía hoy, constituyen uno de los más significativos conjuntos de materiales arqueológicos del actual Museo Municipal de San Roque que, popularmente, es conocido por todos los sanroqueños como la «colección Santa-Olalla» (FIGURA 7).

A la vista de los resultados que obtuvo y con la perspectiva que da el tiempo, creemos que -sin caer en la exageración- sorprende la visión que este investigador tuvo del yacimiento en una

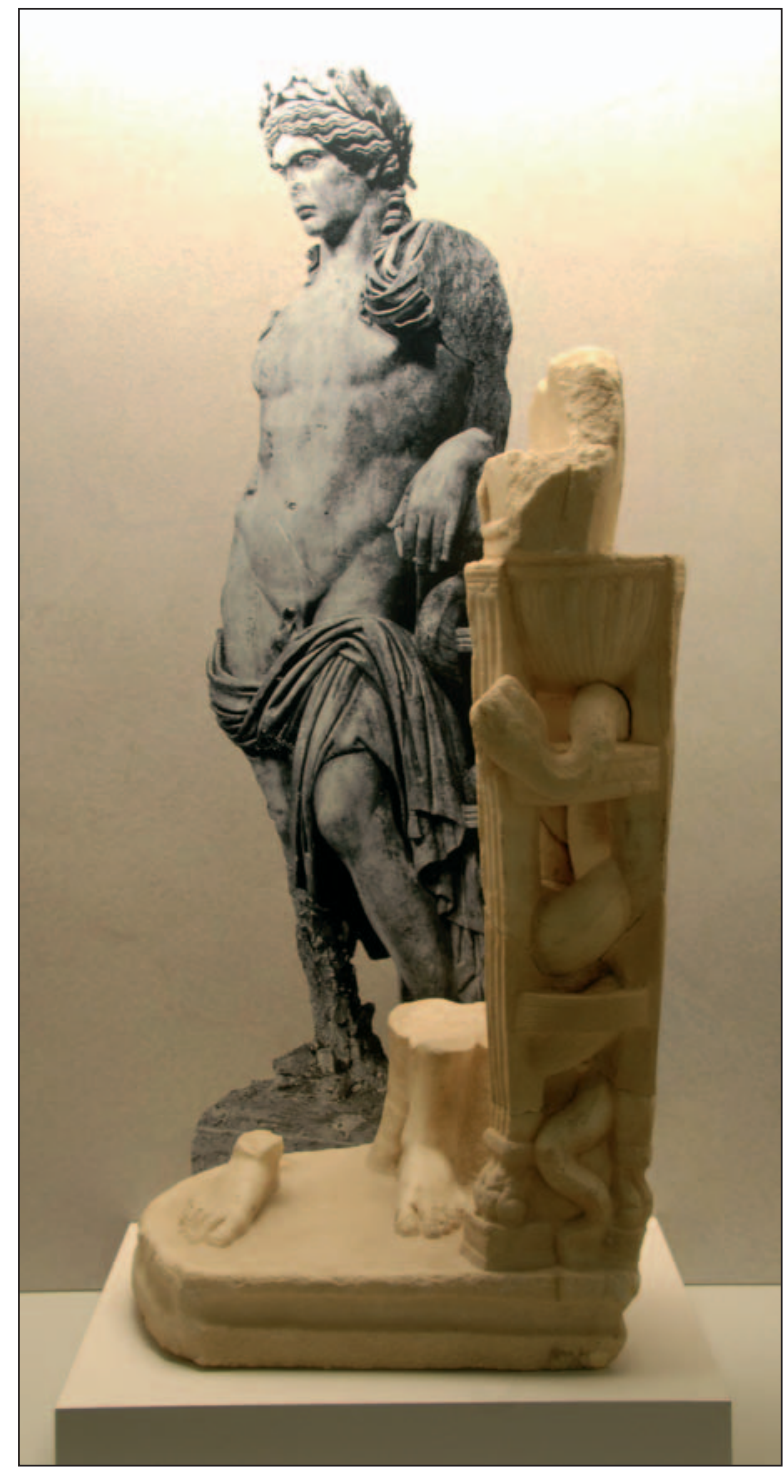

Figura 7. Montaje actual que hemos efectuado con la "estatua de Apolo", aparecido en el edificio termal de Carteia. Museo Municipal de San Roque. (C) Proyecto Carteia de la UAM, (2012). época -conviene no olvidar- como fue la década de los años 50. Así, sus actuaciones arqueológicas no se limitaron al interior del recinto amurallado, como sí hicieron con posterioridad los equipos de Woods y Presedo, sino que abarcaron también zonas periféricas: excavó en la necrópolis del Huerto del Gallo; mejoró los accesos al propio yacimiento; ajardinó y repobló con especies vegetales la zona sur del mismo y llegó a involucrar al propio Ayuntamiento de San Roque en un plan de ordenación urbana de la barriada de Guadarranque, aneja al yacimiento, a la que llegó a cambiar el nombre por el de "barriada" de Carteia. Consiguió, incluso, sensibilizar a dicha institución municipal en la necesidad de construir un museo.

Sus excavaciones en Carteia estuvieron caracterizadas por dos pautas fundamentales. Por un lado, por la diversidad de las áreas intervenidas y que, durante décadas, de manera errónea, han sido atribuidas a posteriores arqueólogos: muralla, termas, teatro, la factoría de salazón situada al sureste de la ciudad y tres de sus necrópolis: la citada del Huerto del Gallo, la de la Torre del Rocadillo y la de las Termas. Por otro y coherente con criterios de su época que han perdurado durante décadas en la arqueología española, sus trabajos estuvieron siempre determinados por localizar y trabajar en los edificios de claro carácter monumental, tan propios de cualquier ciudad romana.

Metodológicamente hablando, Julio Martínez Santa-Olalla estaba educado en la escuela arqueológica alemana, por entonces imperante en Europa. Ello le posibilitó aplicar en Carteia actuaciones ciertamente novedosas o, cuando menos, poco frecuentes en la arqueología española del momento. Valgan como ejemplos de esta afirmación el que aplicara un sistema de excavación en cuadrículas; el haber documentado los hallazgos más significativos en adecuadas planimetrías; la realización de un importante corpus fotográfico (FIGURA 8) -hoy en estudio- atento, no sólo a los principales hallazgos sino también al propio proceso de las excavaciones; o el haber contado con la colaboración de la Base Naval de Rota para realizar un fotoplano aéreo de la ciudad y fotografías a baja altura, "de detalle de los monumentos y del área amurallada".

Figura básica para entender la arqueología española de la postguerra española de los años 40, su filiación política todavía hoy creemos pesa en exceso a la hora de valorar su actividad científica, 


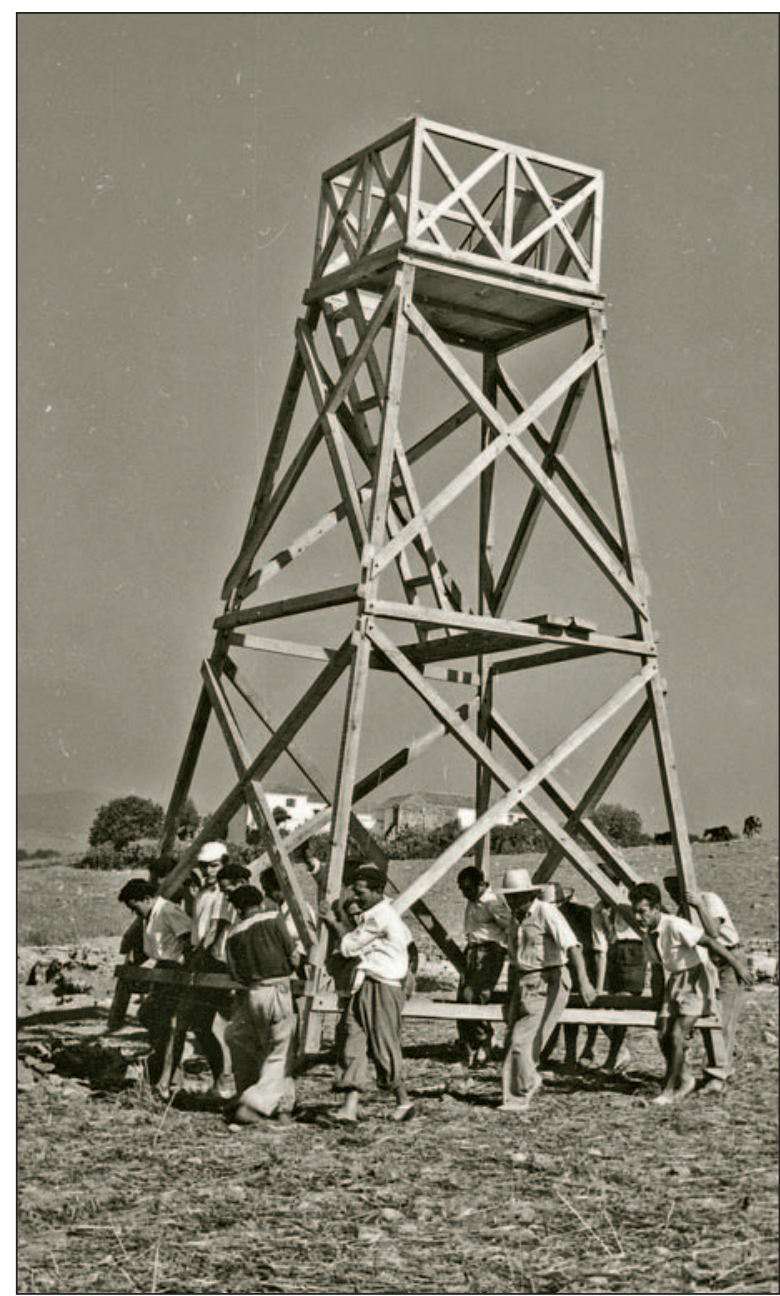

Figura 8. Torre para fotografías mandada hacer por Julio Mtnez. Santa-Olalla para sus excavaciones en Carteia. (C) Museo Arqueológico Nacional, Madrid. Legado J. Mtez. Santa-Olalla, $n^{\circ}$ inv. 1973-58-FF-10232 (028). Segunda mitad década años 50.

hasta el punto que, tanto su persona como sus investigaciones, siguen hoy rodeadasde polémica. Discípulo de Pedro Bosch Gimpera y Hugo Obermaier, abarcó a lo largo de su carrera científica una amplia temática de estudios: prehistoria, edad del bronce, periodo romano y etapa visigoda, tanto en la Península Ibérica como en las Islas Baleares. De igual manera desarrolló un notable interés por la prehistoria norteafricana, con estancias en Marruecos, Sahara Occidental y Canarias (Mederos, 2012:76). Sus planteamientos ideológicos, así como la época que le tocó vivir, indudablemente, condicionaron su actividad científica y hasta su propia concepción de nuestra historia peninsular pero, justo es reconocerlo, su paso "arqueológico" por el yacimiento de Carteia fue incuestionablemente positivo y marcó, como decíamos, un verdadero un punto de inflexión en el conocimiento científico de esta ciudad del Estrecho.
Su planteamiento extremadamente nacionalista de la arqueología, defendido en su "Esquema Paletnológico" (1941), su "visión de la prehistoria que habría de sostener la España de los vencedores" o su teoría de la "completa arización de España", puesta de manifestó en "La indoeuropeización de España" (1950), condicionó toda su labor docente y científica. No obstante, creemos objetivo defender su indudable capacidad de gestión, así como sus aportaciones a la renovación del método científico en la arqueología española de la postguerra.

Fue Lector de español y Cultura Española en la universidad alemana de Bonn, entre los años 1927 y 1931, con objeto de completar su formación (Mederos y Escribano, 2011: 117). Ello terminó por definir su perfil académico, así como su pensamiento político filo alemán, cuestión ésta traslucida en toda su trayectoria científica... y personal. A su regreso a España se incorporó a la Universidad Central de Madrid en calidad de Ayudante en la Cátedra de Historia Primitiva del Hombre ocupada, por aquel entonces, por Hugo Obermaier. Formó parte del Seminario de Historia Primitiva del Hombre y colaboró en la formación de su importante biblioteca, de su colección de objetos arqueológicos, en su significativo fondo fotográfico y en la publicación de Cuadernos de Historia Primitiva.

Su carrera científica fue especialmente fructífera en las décadas de los años 30 y 40 . Acometió estudios sobre el neolítico andaluz e hispano, el campaniforme, la cultura céltica y la cultura ibérica. Su larga, pero agitada, carrera docente favoreció el que ocupara sucesivas cátedras: la de Historia del Arte y de Arqueología, en la universidad de Santiago de Compostela (1936-1939); la de Historia Primitiva del Hombre, en la citada Central de Madrid (1939-1954); de nuevo otra sobre Historia del Arte, esta vez en Zaragoza (1954-1957) y en Valencia (1959); y, por último en la Central de Madrid (1965-1972), que ya ocupó hasta su muerte en 1972.

De manera paralela, dada su citada afiliación al Régimen, le permitió ocupar diferentes cargos de responsabilidad ministerial siempre en relación con la gestión del Patrimonio como, por ejemplo, la Comisaría General de Excavaciones (1940). Ello le otorgó un gran poder e influencia internacional, no exenta de manifiestos desencuentros con buena parte de la comunidad académica española, así como establecer colabora- 
ciones con numerosas instituciones académicas. $\mathrm{Su}$ incesante capacidad de gestión le llevó a crear el Instituto y Museo de Arqueología Municipal de Madrid (1953), en la famosa Quinta de la Fuente del Berro y que llegó a dirigir durante casi 20 años.

En Carteia acometió una intensa labor que, lamentablemente, apenas llegó a publicar, excepción hecha de algunas notas. Pero de ello no deberíamos deducir falta de interés por el yacimiento. De hecho, la tesis doctoral de uno de sus discípulos, colaborador en el Seminario de Historia Primitiva del Hombre, C. Posac Mon, versó sobre El Estrecho de Gibraltar en la Antigüedad clásica (1984), si bien terminó dirigida por J.M. Blázquez tras el fallecimiento de Santa-Olalla (Mederos y Escribano, 2011: 160).

Sin embargo hoy, por primera vez, contamos con datos fehacientes acerca de aquellos trabajos arqueológicos desarrollados entre los años 1953 y 1962. Nos referimos, por un lado, a las cerca de 400 imágenes fotográficas de sus excavaciones en Carteia, hoy guardadas en el Museo Arqueológico Nacional de Madrid y, por otro, a través de correspondencia y papeles administrativos guardados, en su mayor parte, en el hoy Museo de Madrid, el antiguo Museo de San Isidro. Los origenes; en el Archivo General de la Administración (AGA), en Alcalá de Henares; en la antigua Fundación Municipal de Cultura "Luis Ortega Brú", del ayuntamiento de San Roque (Cádiz), así como por recientes estudios biográficos (Mederos y Escribano, 2011; Gracia, 2009; Roldán y Blánquez, 2012).

Así, por ejemplo, a través de estos últimos, podemos pensar que Santa-Olalla podría haber empezado a excavar en el yacimiento con anterioridad, pues en la contabilidad del ayuntamiento sanroqueño de 1953 aparece la cantidad de 1.953 pesetas para subvencionar las excavaciones que desde 1949 realizaba Santa-Olla en Carteia (Pérez, 2011: 378). En este mismo sentido, de 1952, se conserva en el AGA un presupuesto de 35.000 pesetas para "excavar en Carteia" junto con Bernardo Sáez Martín y Luis Oleada Ruiz de Azúa (Mederos y Escribano, 2011: 332; Gracia, 2009: 332-33). Pero en ambos casos no hay ninguna otra constancia de que estas actividades se hubieran levado a cabo. También se conserva la justificación de un presupuesto de 50.000 pts. para excavar en Carteia, ya en 1954, y de nuevo, tras perder la cátedra de Madrid, de 25.000 pesetas más, esta vez a nombre de Bernardo Sáez (Mederos y Escribano, 2011: 334; Gracia 2009: 396-397).

Por otro lado, más allá del año 1962 no han aparecido, por el momento, más documentos acerca de su continuidad arqueológica en el yacimiento. Tan sólo, de 1964, se conoce por la correspondencia que guarda el Museo Arqueológico de Sevilla una carta de FernándezChicarro dirigida al profesor A. Arribas en la que se proponen nuevas excavaciones en Carteia y en la que, la entonces directora del Museo, indica cómo fue ella quien propuso contar para excavar en Carteia, tanto con el profesor Collantes como con el propio Santa-Olalla. No obstante, sabemos que este último no llegó nunca a incorporarse a esta nueva etapa de la investigación en Carteia al aducir éste motivos de salud.

Por la correspondencia conservada, así como por algunas notas de prensa de aquellos años podemos hoy recuperar alguna información interesante de su actividad científica, técnica, museográfica y docente que, en ocasiones, llega a ser sorprendente. Así, podríamos destacar, entre otras, su petición de "un fotoplano del área de Carteya", de fotografías a poca altura o de detalles de los monumentos y del área amurallada a D. Eduardo Gener Cuadrado, en aquel entonces 1960- Almirante Jefe de la Base Naval de Rota, sugiriendo "por si pudieran hacerlas aprovechando las horas de vuelo en el campo de Gibraltar"; o su iniciativa para inaugurar un nuevo museo en San Roque y, vinculado a ello, la adecuación del yacimiento a las visitas y la mejora de sus accesos con la colaboración de la Diputación de Cádiz. En relación con esto último el ayuntamiento de San Roque llegó a aprobar, a finales de 1959, un "plan de reorganización urbana de la barriada de Guadarranque" (Roldan y Blánquez, 2011a).

También tenemos conocimiento de cómo, en 1959, se dirigió al Ministerio de la Vivienda y al Distrito Forestal en Sevilla para solicitar la "repoblación de especies vegetales en armonía con el paisaje y ambiente histórico...", así como el "ajardinamiento y repoblación de las ruinas de Carteya". Por último, tenemos constancia de su interés por crear un Campo Universitario de trabajo arqueológico en la cercana localidad de Guadiaro, inmediata a la también romana ciudad de Barbesula. 
Pero mayor lujo de detalles permite hoy el pormenorizado análisis estudio de las imágenes fotográficas. En este sentido, uno de los aspectos más interesantes ha sido la posibilidad de ubicar los lugares exactos de aparición de importantes piezas arqueológicas -hasta la fecha descontextualizadas- procedentes de sus excavaciones arqueológicas y que, en la actualidad, forman parte de la colección del Museo Municipal de San Roque. Dicha documentación fotográfica, junto con interesantes manuscritos personales y documentos administrativos, fueron adquiridos por el Museo Arqueológico Nacional tras la muerte del investigador, cuando era su director el profesor Martín Almagro Basch y que hoy acometemos gracias a la amable invitación para así hacerlo de la anterior directora del MAN, Rubí Sanz Gamo y de las facilidades dadas en el Departamento de Documentación de dicho Museo

Así, por ejemplo, hemos podido identificar piezas escultóricas provenientes de la excavación del edificio termal y que, por ello, pensamos que debieron formar parte del programa decorativo del mismo, cuestión ésta, hasta la fecha, prácticamente desconocida en la ciudad de Carteia. Nos referimos a una escultura de Apolo, en mármol, a cuya calidad escultórica se une ahora el conocimiento de su contexto (Roldán, 2009) (FIGURA 9 a y b).

Pero la propia metodología de excavación también hoy podemos detallarla a través de las citadas imágenes fotográficas, así como -y del máximo interés- el entorno físico del yacimiento, desprovisto totalmente de vegetación, o del Cortijo del Rocadillo, todavía en explotación. Estos aspectos, junto con el "seguimiento" de los obreros fotografiados durante las excavaciones, han permitido, en la práctica, rastrear sus "pasos arqueológicos" y saber, así, cómo Santa-Olalla llegó a excavar más de dos tercios del edificio termal que hoy se puede visitar; prácticamente, todo lo conservado de la scaena del teatro; diferentes puntos de la muralla, al norte y al oeste de la ciudad y las tres necrópolis citadas con anterioridad en este texto.

\section{Nuevos datos a CERCA de LA CIUDAd DE CARTEIA Y SU ENTORNO PERIURBANO}

Como decíamos, otro de los aspectos relevantes del estudio de las imágenes fotográficas de Julio Martínez Santa-Olalla ha sido el poder observar interesantes detalles acerca del ámbito externo cercano al yacimiento (FIGURA 10). Se trata de una cuestión, creemos, muy importante dada la profunda transformación topográfica y de manto vegetal sufrida en toda la Bahía a raíz de su industrialización acelerada al final con motivo del cierre definitivo de la verja de Gibraltar el 8 de junio de 1969.
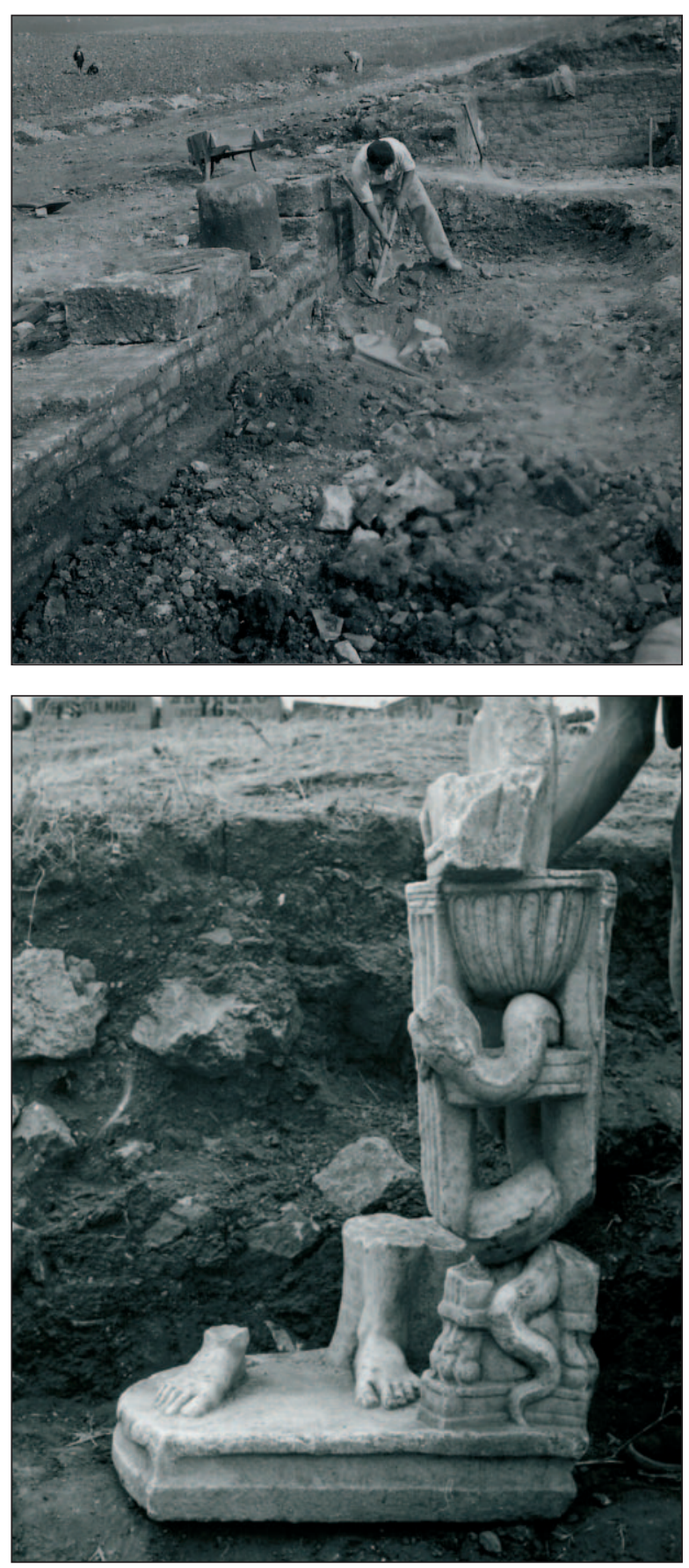

Figura 9 a $y \boldsymbol{b}$. Excavación del caldarium de las termas de Carteia en el momento de aparición del "Apolo" y detalle. (C) Museo Arqueológico Nacional, Madrid. Legado J. Mtnez. Santa-Olalla, ${ }^{\circ}$ inv. 1973-58-FF10115(007) y 58-FF-10232 (063), respectivamente. Década años 50. 


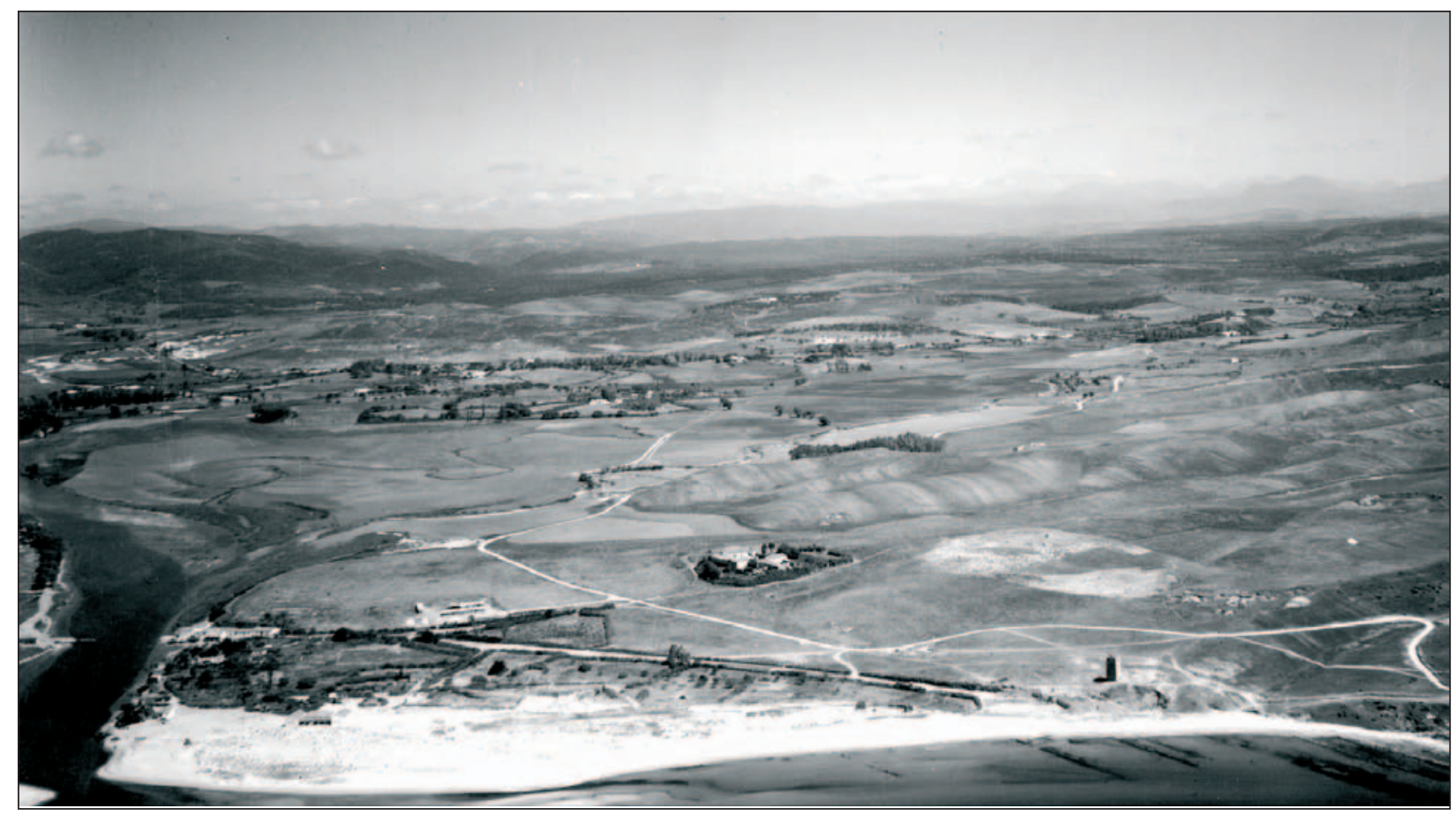

Figura 10. Montaje fotográfico de la antigua desembocadura del río Guadarranque. (C) Centro Cartográfico y Fotográfico. Ejército del Aire, Madrid; n n inv. 5188 (01)-1 ${ }^{\mathrm{a} I H C A,} 5186$ (03)-1 ${ }^{\mathrm{a} I H C A}$ y 5188 (02)-1 ${ }^{\mathrm{a} I H C}$, (1956).

Así, por ejemplo, en relación con la muralla, la documentación gráfica nos muestra la planta conservada de un importante tramo de la misma y, junto a ella, los trabajos de excavación en uno de sus bastiones semicirculares -todavía hoy visibleal sureste de la ciudad. De hecho, en su Informe redactado en 1953 alude, de manera expresa, a sus características: Forma un polígono irregular sobre el talud del Guadarranque y hacia el mar se apoya en los acantilados que dominan la playa (...) Forma una maciza avenida de casi cuatro metros de espesor compuesta de dos elementos: un núcleo de mampostería y un paramento de piedras cortada". En este sentido, durante recientes trabajos de excavación llevados a cabo por nosotros (campaña de 2009) pudimos documentar en la denominada "Área 113", un nuevo lienzo del trazado de la muralla romana, sólo que en este caso en el sector suroccidental de la ciudad (FIGURA 11). Corría éste paralelo, por fuera, al anterior trazado de la muralla púnica que, en esta zona, conserva hoy más de 4 metros de potencia. Se descubrieron nueve metros de longitud del lienzo romano, lo que permitió caracterizar su sistema constructivo con todo detalle.

Con respecto a la muralla púnica, desde el año 2009 nos es mucho mejor conocida dado su incuestionable buen estado de conservación. Sabemos que fue levantada con sillares de piedra caliza, de diferente tamaño, si bien siempre tallados con bastante esmero. Por su cara interna (al Este) se pudieron documentaron dos muros perpendiculares a la muralla, más un tercero insinuado, todos ellos bajo un pavimento de opus signinum o más estrictamente de hormigón hidráulico. Dispuestos los tres a igual distancia unos de otros $-3,30$ m.- resulta fácil defender que nos encontramos, de nuevo, ante una muralla de casamatas o casernas semejante a ya publicada en la parte sur de la ciudad púnica (Roldán et alii, 2006).

Pero volviendo al tema que nos ocupa, en esta misma área de excavación (Área 113) y en paralelo al lienzo murario antes comentado, más al Oeste, se documentó una segunda muralla, esta vez de época romana, así como una antigua calera todavía sin vaciar de posible época tardía. El nuevo lienzo murario, de tres metros de grosor, dada la amplia extensión del área excavada pudo documentarse en tres estadios diferentes en cuanto a grado de conservación. De Sur a Norte, primero, tan sólo al nivel de su zapata de cimentación; más hacia el Norte conservaba ya parte de su original cimentación en alzado, sistema éste empleado en su construcción; y, por último, en el extremo del Área 113, ya el alzado propiamente dicho acometió mediante sillares de biocalcarenita bien escuadrados. El alto grado de degradación -podemos defender una altura original cercana a 


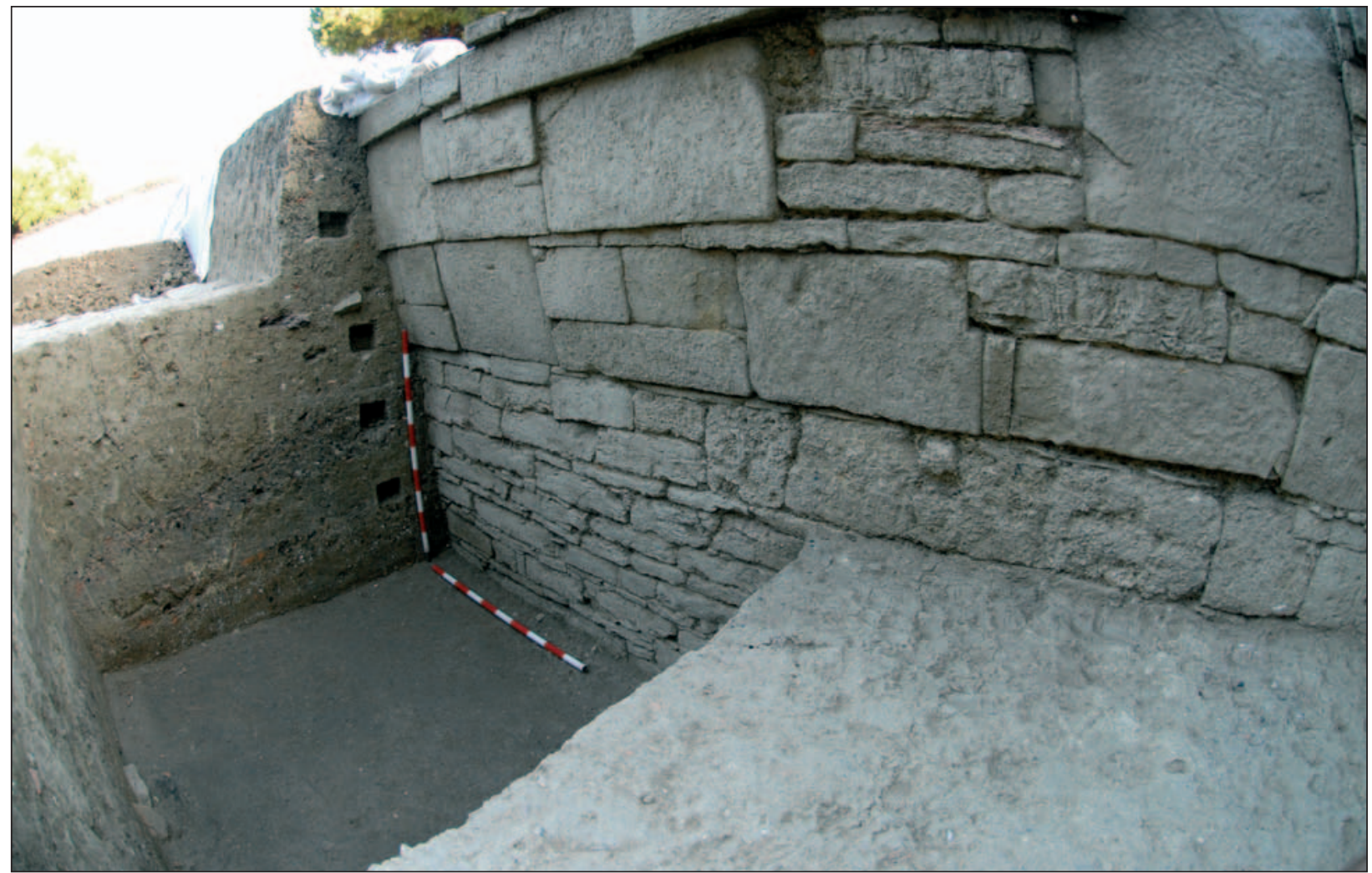

Figura 11. Vista parcial del "Área 113”, con la muralla púnica -bárquida- de Carteia (sector occidental), finales s. III a.C. Campaña de 2009. (C) Proyecto Carteia de la UAM (2009).

los 9 metros- es evidente que, al menos es este sector de la ciudad, se debió a un sistemático expolio de sus piedras, primero, probablemente, para acometer nuevas construcciones y después, ya con seguridad, para la obtención de cal. La parte positiva del citado expolio es el habernos posibilitado estudiar de manera detallada su sistema constructivo y, muy especialmente, de cimentación: la cara al interior de la ciudad mediante la típica zapata con base de apoyo, excavada en la tierra geológica, de sección ovalada; por el contrario, al exterior y como consecuencia de la fuerte pendiente natural presente en todo el perímetro externo de la ciudad, tuvo que construirse una cimentación más cuidada - escalonada- que generó una equívoca "cara vista" que nunca fue tal.

La muralla romana aparecida, conservada en esta área excavada en más de $20 \mathrm{~m}$. de longitud, estaba dispuesta de manera paralela al trazado de la anterior púnica. Ello y el que dicho paralelismo esté desviada con respecto a su alineación general en toda la parte Oeste de la ciudad apunta a que, bajo nuestro punto de vista, dicho desvío puntual e intencionado respondería a la intención de ir su trazado a "encontrarse" con la antigua puerta púnica y que ésta debe de hallar a muy pocos metros del actual límite del Área 113 excavada en la campaña de 2009.

\section{LAS Necrópolis de LA CIUdAd DE CARTEIA}

Las imágenes fotográficas del Legado documental de Martínez Santa-Olalla del MAN, así como la cartografía levantada por A. Gómez y F. Jiménez en 1958, dentro de las actuaciones del Seminario de Historia Primitiva (FIGURA 12), cuyas copias se conservan hoy en el Legado Presedo, ofrecen también importante información acerca del conocimiento de varias de las necrópolis de la ciudad Carteia. De algunas de ellas, ni siquiera se tenían noticas de su existencia caso, por ejemplo, de la situada junto a la Torre del Rocadillo, extramuros; de otras, como la casi hoy desparecida existente al SW de las termas, se tenía muy poca documentación, y eso que la historiografía moderna ha hecho continuas referencias a la existencia de diversas necrópolis en Carteia. Recientemente, una intervenciones arqueológica de urgencia ha permitido documentar una nueva necrópolis situada, en esta ocasión, extramuros junto a una de las puertas de la ciudad 


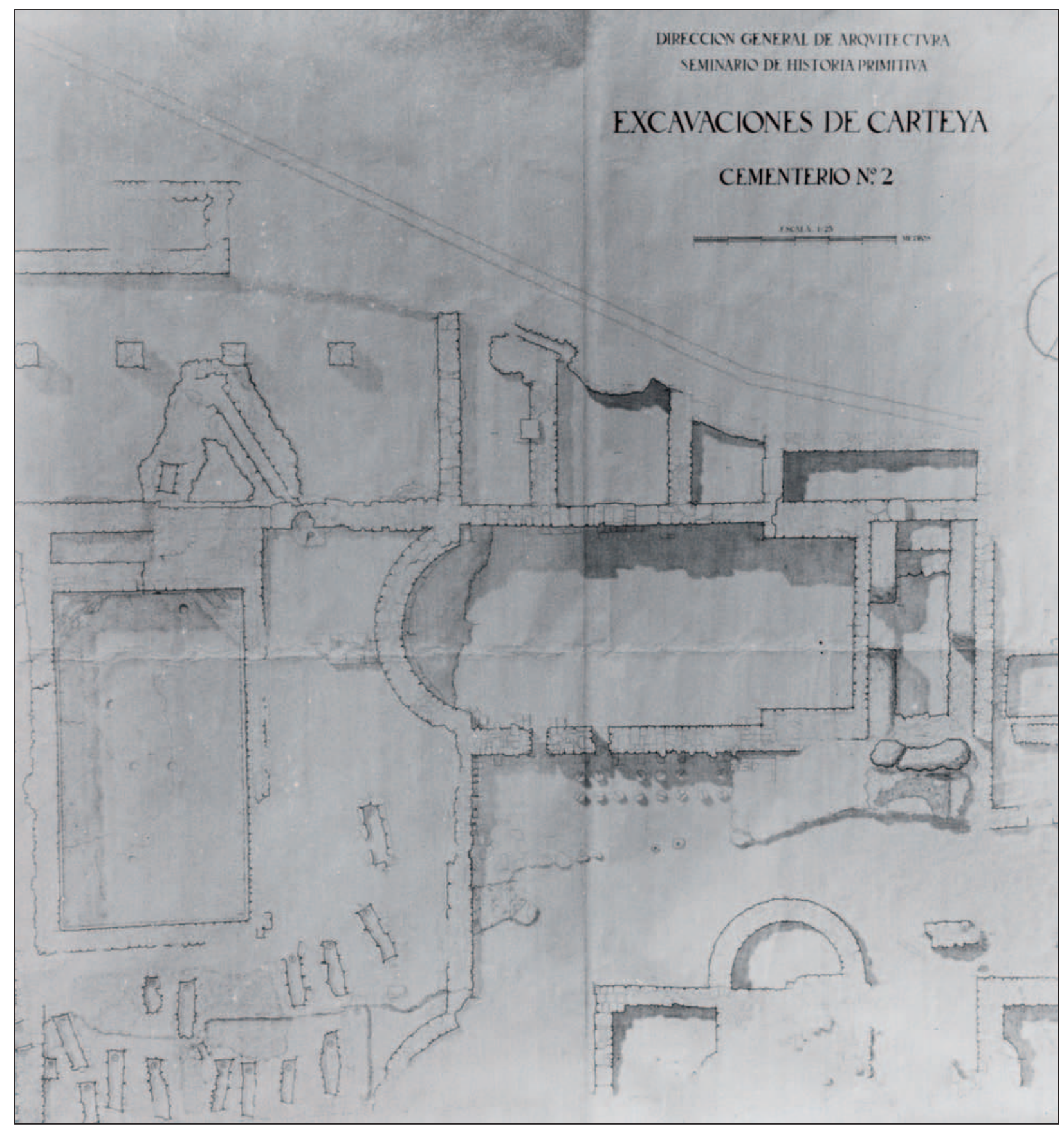

Figura 12. Plano parcial de las termas de Carteia con la planimetría del "Cementerio 2". Dirección General de Arquitectura. Seminario de Historia Primitiva. Excavaciones en Carteya. (C) Legado F. Presedo. Gentileza A. Caballos. Posterior a 1957.

(Gestoso y López, 2009). De todas ellas, por su extensión y por los materiales en su día aparecidos, dos son las necrópolis especialmente interesantes para estudiar a través de la documentación gráfica conservada en el Legado fotográfico de Martínez Santa-Olalla: la de las termas (Cementerio 2, según nomenclatura de su excavador) y la del "Huerto del Gallo, de la que lamentablemente no ha aparecido -hasta el momento- cartografía alguna. Si croquis en uno de sus Diarios de Excavación.
Con respecto a la primera, de época tardoantigua, hoy poco se conserva pero gracias al detallismo fotográfico con que Santa-Olalla llevó a cabo su excavación podemos caracterizarla de manera suficiente (FIGURA 13). La notable densidad de enterramientos aparecidos en su día confirma, sin duda, la importancia de esta original área termal reocupada como lugar de enterramiento en la Carteia de los siglos VI y VII d.C. (Bernal, 2011b). La necrópolis, junto con la cons- 


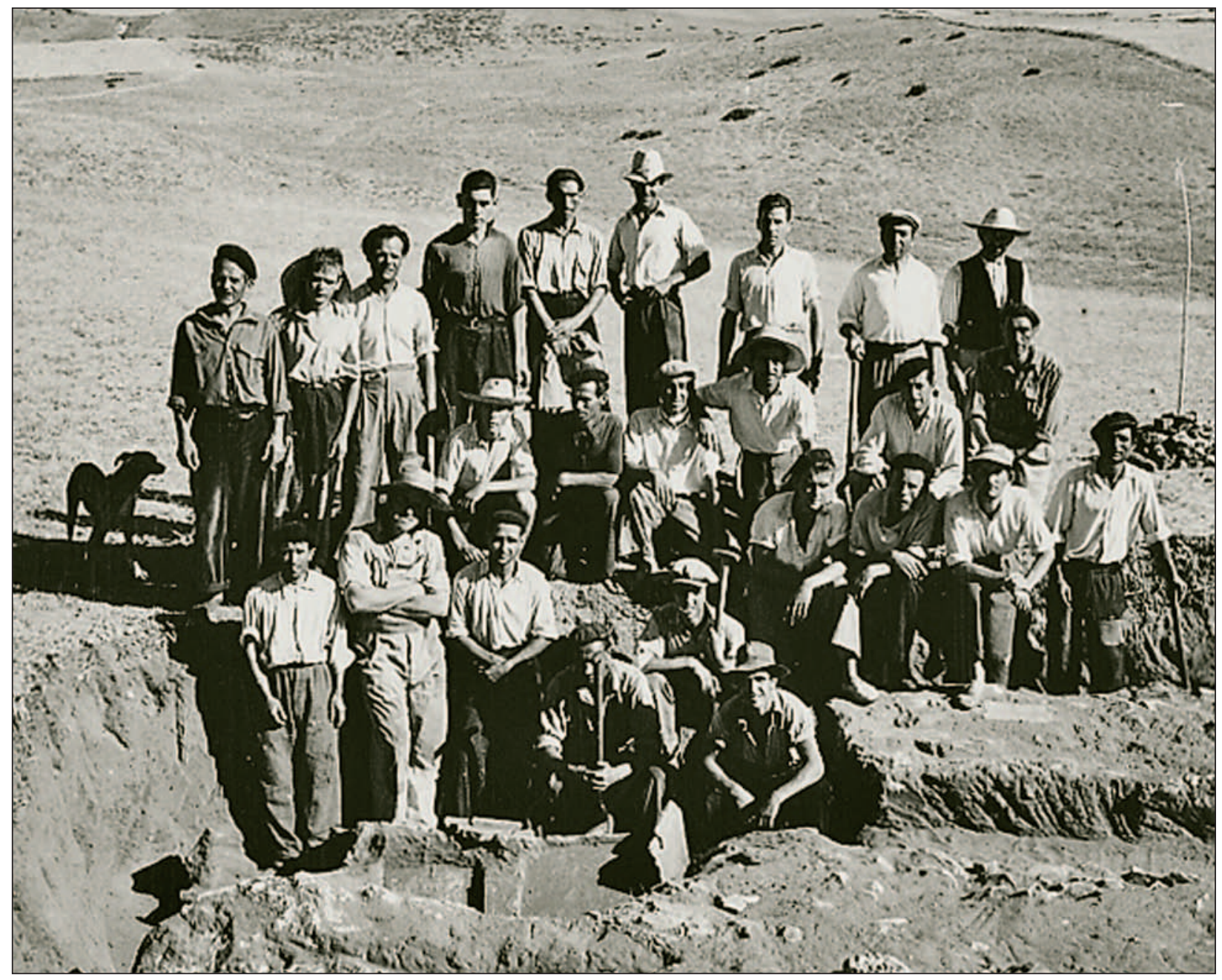

Figura 13. Equipo de obreros que excavó la necrópolis del "Huerto del Gallo". (C) Museo Arqueológico Nacional, Madrid. Legado J. Mtnez. Santa-Olalla. Foto J. Mtnez. Santa-Olalla, no inv. 1973-58-FF-10121(003). Hacia 1955.

trucción de una planta basilical, también excavada por aquel arqueólogo, constata la existencia de -al menos- dos basílicas intramuros de Carteia. Ello pone de relieve el importante papel de esta ciudad también durante la Antigüedad Tardía.

En cuanto a la necrópolis que excavó en la finca denominada "Huerto del Gallo" tiene especial interés por ser el lugar donde ya había parecido en 1840 un tablero de mármol con decoración de guirnaldas y bucráneo (Valverde, 18452003: 329), hoy pieza emblemática del Museo Municipal de San Roque, así como el sarcófago estrigilado citado con anterioridad que hoy se conserva en el Museo de Cádiz (Casaus, 1989: 282; Pérez, 2008: 64-64). Nos parece bastante plausible el que Martínez Santa-Olalla, acicatado por la importancia de estos dos antiguos hallazgos, pusiera su empeño en la localización concreta de la necrópolis para acometer su excavación; tal y como hizo. Para tal fin y por las fotografías sabemos hoy que organizó una serie de largas zanjas paralelas y entrecruzadas en dicho huerto, lo que le permitió localizar el lugar preciso donde se encontraba la necrópolis: un área de dunas marinas consolidadas inmediatas a la línea de costa que, en este punto de la Bahía, apenas ha cambiado en su trazado. También por las fotografías que tomó durante el proceso de la excavación hoy hemos podido estudiar la disposición de los ajuares en sus tumbas, hacer una tipología de enterramientos y ubicar -inclusoalgunos de los epígrafes funerarios, hasta hoy descontextualizados y sobre los que luego volveremos (FIGURA 14).

La necrópolis del Huerto del Gallo estaba compuesta -en función de la parte excavada por Santa-Olla- por sencillas tumbas de inhumación excavadas en la arena y parecida, pues, a que la que hace pocos años hemos excavado en Villa Victoria (Blánquez et alii, 2006). Hemos podido 


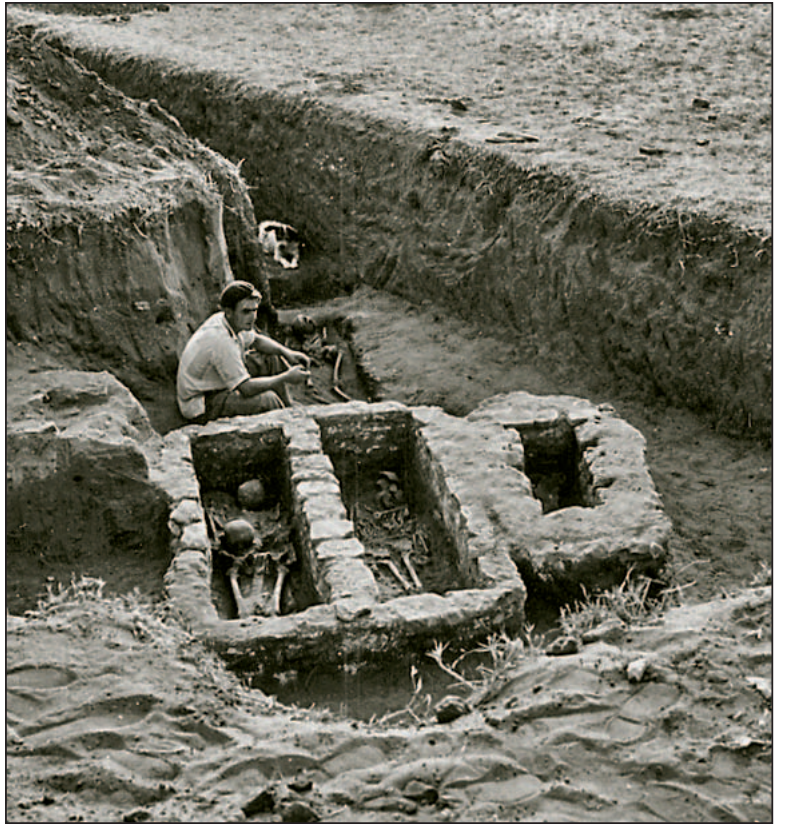

Figura 14. Enterramientos dobles de la necrópolis del "Huerto del Gallo". (C) Museo Arqueológico Nacional, Madrid. Legado J. Mtnez. Santa-Olalla. Foto J. Mtnez. Santa-Olalla, ${ }^{\circ}$ inv. 1973-58-FF-10120(010). Hacia 1955

tipificar enterramientos en cista con cubierta de tegulae, dispuestas a doble vertiente, así como encachados de grandes lajas con cubiertas de piedras irregulares. Algunas de las tumbas poseían piezas de ajuar visibles en las fotografías y que fueron depositadas por Santa-Olalla en el antiguo museo de San Roque, donde se conservan. No hay testimonio fotográfico de la existencia de tumbas de cremación pero sí, por el contrario, en el citado barrio alfarero de Villa Victoria; de ahí el que defendamos la coexistencia de ambos ritos funerarios -inhumación e incineración- al menos durante los siglos I y II d.C. De los hallazgos epigráficos, tal y como apuntábamos, querríamos destacar los de Annio Senicio y Valeria Fausta. El primero, sobre una laja de pizarra esquistosa de forma triangular y que se puede datar en el siglo II d.C. por los rasgos paleográficos (FIGURA 15). La inscripción puede traducirse como «Gayo Annio Senición, hijo de Gayo, adscrito a la tribu Galeria, lo hizo para él y los suyos» (Del Hoyo, 2006: $n^{\circ} 14$ y 22). La segunda, inédita, no se conoce su ubicación actual.

Por los tipos de tumba y, sobre todo, por los materiales aparecidos la necrópolis del Huerto del Gallo podemos fecharla, al menos, en el siglo II d.C., si bien pudo extenderse antes y después de este periodo. Nos encontramos, por tanto, ante una de las necrópolis altoimperiales de la ciudad de Carteia, ubicada al sureste de la misma, junto a la playa y en el entorno inmediato de la vía de la costa (Corzo y Toscano, 1992) con dirección a Calpe. Aun con todo, su continuidad en el tardoimperio parece estar demostrada por el hallazgo, también en este lugar, del citado sarcófago estrigilado.

Procedentes de las excavaciones de SantaOlalla pero sin saber -por el momento- el lugar concreto de procedencia, tenemos tres inscripciones más y un fragmento de una cuarta más. Cronológicamente, una de ellas corresponde a la segunda mitad del siglo I (Gaius Cornelius Quadratus) y dos más (Iulio Evandro y Mnester) al siglo III. Existe la noticia de una cuarta inscripción procedente del Huerto del Gallo -un hallazgo casual de 1927- de Aurelium Felix, fechada en los siglos IV-V d.C. y única inscripción cristiana. De 1940 se conocen dos hallazgos casuales más, hoy depositados en el Museo de Cádiz, registrados como procedentes de las "ruinas de Carteia" y que se se fechan entre fines del siglo II o comienzos del siglo III (Valerio Antestio), el primero; y del siglo III (Felicia), el segundo. Por último, otro hallazgo en Carteia se produjo en 1981, que se puede fechar también a fines del siglo II o comienzos del siglo III (Cesia Tyche). Estas inscripciones han sido datadas por

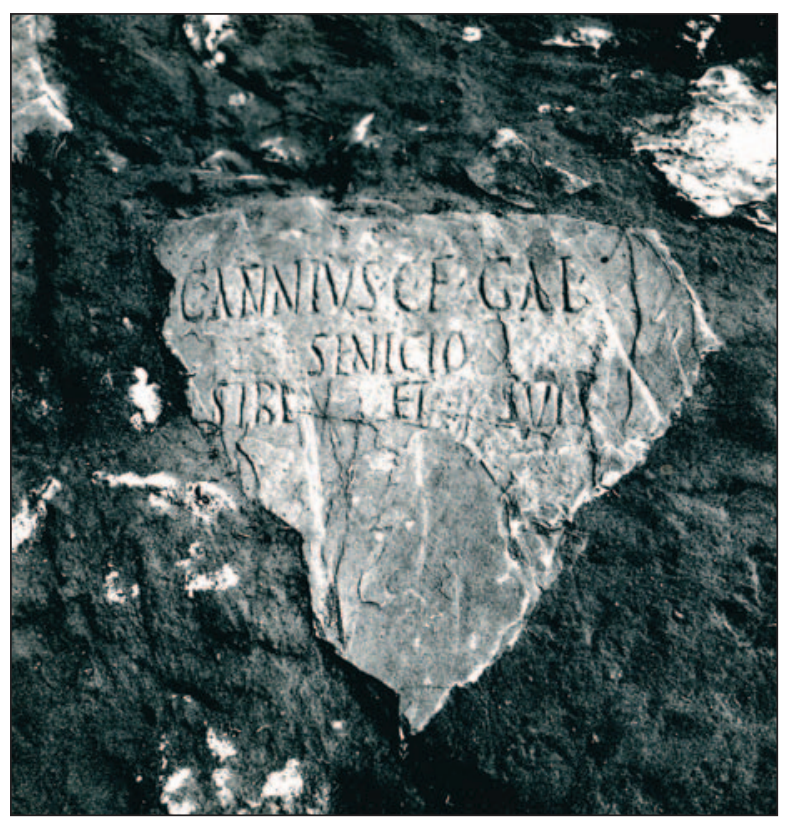

Figura 15. Epígrafe funerario aparecido, posiblemente, en la necrópolis del "Huerto del Gallo". Finales del s. II d.C. (C) Museo Arqueológico Nacional, Madrid. Legado J. Mtnez. Santa-Olalla. Foto J. Mtnez. Santa-Olalla, $\mathrm{n}^{ }$ inv. 1973-58-FF-10561(03). Hacia 1955. 
sus rasgos paleográficos y, en algún caso, por la fórmula sepulcral (Del Hoyo, 2006).

La ausencia de epígrafes de época republicana e, incluso, durante la mayor parte del siglo I d.C. nos invita a reflexionar sobre el lugar de ubicación de la, o las, necrópolis republicanas y altoimperiales más antiguas ya que, por lo que vamos conociendo de la original paleografía del entorno, no parece que estuvieran ubicadas al sur de la ciudad. La ya citada reciente intervención de urgencia, al oeste de la ciudad, en terrenos de la refinería Gibraltar-San Roque de Cepsa y que sus excavadores fechan entre finales del siglo II y el siglo III (Gestoso y López, 2009) aconseja descartar también este sector como zona de emplazamiento de necrópolis más antiguas...

\section{El LEGAdo FOtográfico de JULIO Martínez SANTA-Olalla Y LA RECONS- TRUCCIÓN DEL PAISAJE CULTURAL DE CAR- TEIA}

La importancia que hoy tiene en todo trabajo arqueológico la investigación historiográfica, asî como la revisión de antiguos trabajos o estudios de Legados inéditos cobran especial interés en el caso de la ciudad de Carteia dada la fuerte transformación topográfica, ambiental y poblacional experimentada en el arco de su Bahía, sobre todo a partir de la década de los años 60 .

Sabemos hoy por crónicas de antiguos viajeros, aquellos "curiosos impertinentes" así como por la muy abundante cartografía y grabados realizados en los siglos XVIII y XIX, cómo el entorno de la Bahía de Algeciras estuvo poblado en la Edad Moderna por cortijos de ricos hacendados gibraltareños dedicados a la actividad agrícola y ganadera (FIGURA 16). Son los casos, entre otros, del Cortijo de San Antonio, del de la Haza del Castellón, del de las Vegas de Prado, o el del Cortijo del Rocadillo. Pero éstos, a su vez, en más de una ocasión se construyeron encima de antiguos asentamientos coloniales que ya habían aprovechado las objetivas ventajas de asentarse en puntos naturales de elevada cota dentro de un entorno de bahía-estuario y playa. Son los casos de los citados Vegas del Prado - encima de una factoría feniciopúnica de "Carteia La Vieja" y el del Cortijo del Rocadillo -sobrepuesto a "Carteia La Nueva"-.

Sabemos hoy cómo el progresivo empantanamiento de la desaparecida "segunda bahía", situada al interior de la actual, en donde hoy se extiende las localidades de Guadacorte y Palmones, a causa de su régimen de estuario y unido a la continuada desforestación de toda la zona que debió iniciarse desde el mismo momento de la fundación de la original factoría fenicia del Cerro del Prado, debió ir transformando parte de su original topografía, así como también su manto vegetal. Aun con todo, a efectos reales, a inicios del siglo $\mathrm{XX}$ los cambios experimentados en su "paisaje" -proporcionalmente hablando- debían de ser mucho menores que los acontecidos, ya de manera radical, a raíz de la construcción de dos polígonos industriales de Guadarranque y Palmones.

En efecto, en la década de los años 50, por voluntad planificadora de la administración del Estado, se favoreció la redacción de los primeros

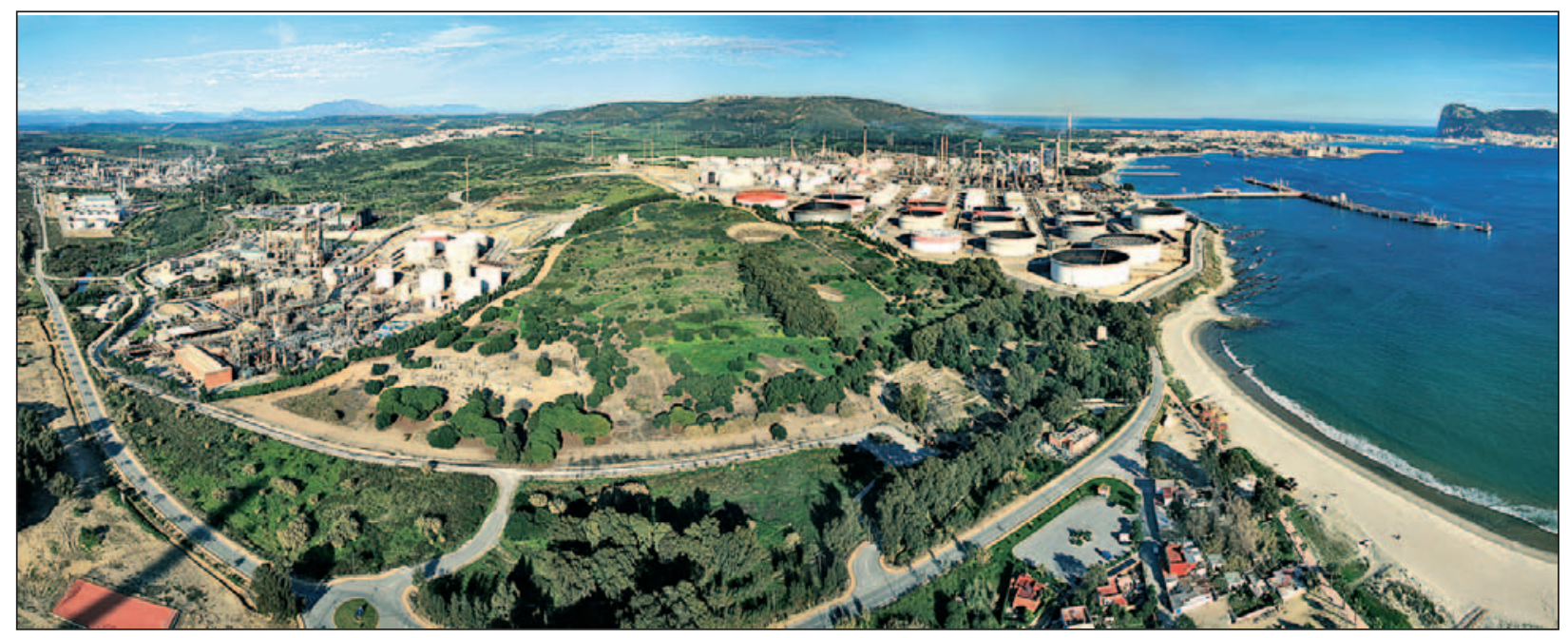

Figura 16. Vista aérea de la ciudad de Carteia, desde el sur. (C) Paisajes Aéreos S.L. Foto J. C. Guzmán Espresati (2010). 
planes urbanísticos como, por ejemplo, el "Gran Bilbao" (1950), "Gran Valencia" (1950) y el "Plan Comarcal de Barcelona" (1953). Todos ellos estaban encaminados a la construcción de viviendas destinadas a paliar el endémico déficit de viviendas detectado en España por el Censo de Población y Vivienda y que, en el año 1950, superaba el millón; si bien desigualmente repartidos y en una población española todavía claramente rural. La Ley del Suelo de 1956, la creación del Ministerio de la Vivienda en 1957 y, con ello, los sucesivos Planes de Desarrollo supusieron la base para el primer intento claro de modernización del Estado en este tema social tras la Guerra Civil (Blánquez y Moncada, 2011: 401 y ss.).

Pero para el territorio que ahora nos ocupa -el Campo de Gibraltar- la radical transformación sufrida por su industrialización estuvo determinada por la respuesta dada por el Estado a la crisis política y económica de la zona, claramente acentuada por el cierre de la frontera con Gibraltar. A consecuencia de ello y con un claro deseo de paliar los efectos negativos de la misma, se creó un Plan de Desarrollo destinado a aplicar "un programa de medidas para el desarrollo económico y social del Campo de Gibraltar". El mismo, afectó a la totalidad de sus municipios y supuso, entre otras consideraciones, la implantación de todo un rosario de alta industria -fundamentalmente energética- de petroquímicas y energéticas: Cepsa, Celupal, Sevillana de Electricidad, Butano, Carbesa...

Quizás como no prevista, pero si pensada, respuesta ha sido el actual Plan General de Ordenación Urbana de San Roque (1987) que ha puesto de manifiesto una realidad "paisajística" resultante de la citada industrialización, de todo un desajuste poblacional y de una desordenada explotación turística... que han transformado, de manera radical y en poco menos de 30 años, el paisaje cultural de casi tres milenios de historia y tiempo transcurrido.

Es evidente, por todo lo expuesto, que el corpus fotográfico del Legado Julio Martínez SantaOlalla, junto con otros archivos tradicionales, por lo general no utilizados por la investigación arqueológica, caso del Centro Cartográfico y Fotográfico o del Archivo Histórico dependientes ambos del Ejército del Aire, permiten, a falta de una sistemática prospección geológica-arqueológica, interesantes acercamientos a la reconstrucción del paisaje cultural de Carteia y su territorio.
En esta labor nos encontramos investigando a través del proyecto Estudios Historiográficos, Paleotopográficos, Paleaombientales y de Cartografía Antigua y que, como justo homenaje, aquí $\mathrm{y}$ ahora presentamos en reconocimiento a tantos los años de docencia, investigación y dedicación a nuestra formación científica dados por el profesor Manuel Bendala Galán. Que así conste y así quede escrito.

\section{Bibliografía}

ARÉVALO, A. y BERNAL, D., (Eds. Cients.), (2007): Las cetariae de Baelo claudia. Avance de las investigaciones arqueológicas en el barrio industrial (2000-2004). Arqueología Monografías. Junta de Andalucía, Consejería de cultura y Univwrsidad de Cádiz. Sevilla.

ARTEAGA CARDINEAU, C. y GONZÁLEZ MARTÍN, J.A. (2006): "El marco geográfico de Carteia". En L. Roldán, M. Bendala, J. Blánquez y S. Mtez. Lillo (Dirs.): Estudio histórico-arqueológico de la ciudad de Carteia (San Roque, Cádiz). 1994-1999 (2 vols. y CD). Serie Arqueología Monografías. Memorias 24. Junta de Andalucía-Universidad Autónoma de Madrid, 6180. Madrid.

ARTEAGA MATUTE, O., HOFFMANN, G., SCHUBART, H. y SCHULZ, H.D. (1987): "Investigaciones geológicas y arqueológicas sobre los cambios de la línea costera en el litoral de laAndalucía Mediterránea. Informe preliminar (1985)". Anuario Arqueológico de Andalucía 1985/II, 117-122.

BENDALA GALÁN, M. (2011): "Los estudios historiográficos en la Arqueología española". En L. Roldán y J. Blánquez (Eds. Cients.), Carteia III. Memorial. Junta de Andalucía, Universidad Autónoma de Madrid y CEPSA, 51-70.Madrid.

BERNAL CASASOLA, D. (1998): Excavaciones arqueológicas en el alfar romano de la Venta del Carmen. Los Barrios (Cádiz). Una aproximación a la producción ánforas en la Bahía de Algeciras en época altoimperial. Ediciones Universidad Autónoma de Madrid, Ayuntamiento de la Villa de Los Barrios. Madrid.

BERNAL CASASOLA, D. (2004): "Bizancio en España desde la perspectiva arqueológica. Balance de una década de investigaciones". En I. Pérez, I y P. Bádenas (Eds.), Bizancio y la Península Ibérica. De la Antigüedad Tardía a la Edad Moderna, 61-99. Madrid. 
BERNAL CASASOLA, D., (Ed. Cient.), (2011a): Pescar con arte. Fenicios y romanos en el origen de los aparejos andaluces. Catálogo de la exposición Baelo Claudia. Conjunto Arqueológico de Baelo Claudia, diciembre 2011-julio 2012. Universidad de Cádiz, Servicio de Publicaciones. Monografías del Proyecto SAGENA 3, Almería.

BERNAL CASASOLA, D. (2011b): "Las necrópolis tardoantiguas de Carteia. Nuevos documentos para su análisis". En L. Roldán y J. Blánquez (Eds. Cients.), Carteia III. Memorial. Junta de Andalucía, Universidad Autónoma de Madrid y CEPSA, 111-150. Madrid.

BERNAL CASASOLA, D. y. LORENZO MÁRTÍNEZ L. (2002): Excavaciones arqueológicas en la villa romana del Puente Grande (Los Altos del Ringo rango, Los Barrios, Cádiz). Una ventana al conocimiento de la explotación económica de la Bahía de Algeciras entre el s. I y el V d.C. Publicaciones de la Universidad de Cádiz, Instituto de Estudios Ceutíes y Ayuntamiento de Los Barrios. Huelva.

BLÁNQUEZ PÉREZ, J. y MONCADA GARCÍA, N. (2011): "El entorno de la ciudad de Carteia: la recuperación de un paisaje cultural". En L. Roldán y J. Blánquez (Eds. Cfcos.), Carteia III. Memorial. Junta de Andalucía, Universidad Autónoma de Madrid y CEPSA., 393-409. Madrid.

BLÁNQUEZ PÉREZ, J. y ROLDÁN GÓMEZ, L. (2007): "Novedades en el asentamiento fenicio de El Cerro del Prado y de la CarteiaPúnica”. En J.L. López castro (Ed.). III ${ }^{\circ}$ Congreso Internacional del Centro de estudios Fenicios y Púnicos: Las ciudades fenicio-púnicas en el Mediterráneo Occidental. Adra (Almería) 2003. Centro de Estudios Fenicios y Púnicos y Universidad de Almería. Almería, 257-280.

BLÁNQUEZ PÉREZ, J. y ROLDÁN GÓMEZ, L. (2009): "Elementos mueble-elementos inmueble. Reflexiones acerca de una definición del horizonte cultural púnico en la ciudad de Carteia, San Roque, Cádiz". VI Coloquio internacional del centro de estudios fenicios y púnicos. Los púnicos de iberia. Proyectos, revisiones y síntesis. Sevilla (e.p.).

BLÁNQUEZ PÉREZ, J, BENDALA GALÁN, M. y ROLDÁN GÓMEZ,L. (2007): "New proposals for colonial settlement models in the phoenician-punic world on the Southern Iberian Peninsula. The exemple of Carteia (San Roque, Cádiz)". Convegno Internazionale Urbanistica Fenicia e Punica. Roma, 21-23 de febrero 2007, Istituto Arqueologico Germanico di Roma. Roma, 515-528.
BLÁNQUEZ PÉREZ, J., ROLDÁN GÓMEZ, L., BERNAL CASASOLA, D. y DÍAZ RODRIGUEZ, J. (2006):"La necrópolis del barrio alfarero de Carteia. Excavaciones en Villa Victoria (San Roque, Cádiz)". IX Jornadas de Arqueología del Campo de Gibraltar. La Línea de la Concepción (e.p.)

CORZO, R. y TOSCANO, M. (1992): Las vías romanas en Andalucía. Sevilla.

CASAUS, J.A. (1989): San Roque. Crónica de un cuarto de siglo (1963-1988). Cádiz.

CHEDDAD, A. (2008): "Pêche et industries annexes en PéninsuleTingitane".En J. González, P. Ruggeri, C. Vismara y R. Zucca (Eds.).L'Africa romana. XVII Convengo Internazionale: Le ricchezzedell'Africa. Risorse, produzioni, scambi, (Sevilla, 2006), vol. 1, Caroccieditore, 387404.Roma.

DEL HOYO, J. (2006): "Corpus epigráfico". En L. Roldán, M. Bendala, J, Blánquez, y S. Mtnez. Lilo (Dirs.): Estudio histórico-arqueológico de la ciudad de Carteia (San Roque, Cádiz). 1994-1999 (2 vols. y CD). Serie Arqueología Monografías. Memorias 24, Junta de Andalucía y Universidad Autónoma de Madrid. Madrid.

ÉTIENNE, R., Y MAYET, F., (2002): Salaisons et sauces de poissonhispaniques. París.

GESTOSO MOROTE, D. y LÓPEZ RODRÍGUEZ, J.I. (2009): La necrópolis altoimperial de Carteia y el mundo funerario romano. CEPSA y Astarté, Estudio de Arqueología. Málaga.

GOZALBES CRAVIOTO, E. (2006): "Documentos epigráficos acerca de las relaciones entre Hispania y Mauretania Tingitana, en A. Akerraz, P. Ruggeri, A. Siraj y C. Vismara (Eds.), L'Africa romana. XVI Convengo Internazionale: Mobilità delle persone e dei popoli, dinamiche migratorie, Emigrazioni ed immigrazioni nelle province occidentali dell'Impero romano (Rabat, 2004), vol. 4, Carocci editore, 1337-1349. Roma.

GRACIA ALONSO, F.(2009): La arqueología durante el primer franquismo (1939-1956). Bellaterra, Arqueología. Barcelona.

HASSINI, H. (2006): “Le Maroc et l'Espagne à l'époque Antique. Échanges commerciauxou marché commun?". En A. Akerraz, P. Ruggeri, A. Siraj y C. Vismara (Eds.), L'Africa romana. XVI Convengo Internazionale: Mobilità delle persone e dei popoli, dinamiche migratorie, Emigrazionie di mmigrazioni nelle province occidentali dell'Impero romano (Rabat, 2004), vol. 4, Carocci editore, Roma. 
JIMÉNEZ-CAMINO, R. y TOMASSETTI GUERRA, J.M. (2005): "Allende el río... Sobre la ubicación de las villas de Algeciras en la Edad Media: una revisión crítica". Primeras Jornadas de Arqueología del campo de Gibraltar. Protección del Patrimonio, Tarifa, 23-25 de Abril de 2004. Boletín de Arqueología Yazarí, 1. Fundación Municipal de Cultura "José Luis Cano". Ayuntamiento de Algeciras. Algeciras, 4-33.

JIMÉNEZ VIALÁS, H. (2011): Colección de cartografía histórica. Tres siglos de imágenes. En L. Roldán (Ed. Cient.), Sinus Carteiensis 1. Universidad Autónoma de Madrid, Ayuntamiento de San Roque y CEPSA. Madrid.

LAGOSTENA BARRIOS, L. (2001): La producción de salsas y conservas de pescado en la Hispania romana (II a.C.- VI d.C.). Colección INSTRUMENTA 11. Universidad de Barcelona, Barcelona.

MARTÍNEZ SANTA-OLALLA, J. (1941): "Esquema Paleontológico de la Península Ibérica”. En J. Martínez Santa-Olalla (ed.): Corona de Estudios que la Sociedad Española de Antropología, Etnología y Prehistoria dedica a sus mártires, I. Consejo Superior de Investigaciones Científicas, 141-166. Madrid.

MARTÍNEZ SANTA-OLALLA, J.(1950): "La indoeuropeización de España". Homenaje a Luis de Hoyos Sainz, II, 378-387. Madrid.

MARTÍNEZ LILLO, S. (2006): "La fortaleza medieval”. En L. Roldán, M. Bendala, J. Blánquez, S. Mtez. Lillo y D. Bernal (Dirs.), Estudio históricoarqueológico de la Ciudad de Carteia (San Roque, Cádiz) 1994-1999 (2 vol. y CD). Serie Arqueología Monografías. Memorias 24. Junta de Andalucía y Universidad Autónoma de Madrid, 503-530. Madrid.

MEDEROS MARTÍN, A. (2012) "El periplo académico de Julio Martínez Santa-Olalla en la década de los cincuenta”. En L. Roldán y J. Blánquez (Eds. Cients), Julio Martínez Santa Ollalla y el descubrimiento arqueológico de Carteia (1953-1961. UAM Ediciones y CEPSA, 69-81. Madrid.

MEDEROS MARTÍN, A. y ESCRIBANO COBO, G. (2011):Julio Martínez Santa-Olalla, Luis Diego Cusco y y la Comisaría Provincial de Excavaciones Arqueológicas de Canarias Occidentales (1939-1955). Tenerife.

MONTERO, F.M. (1860): Historia de Gibraltar y de su campo. Imprenta de la Revista Médica. Cádiz.
MORELL, J.P., 2006: "Notes sur les relations économiques et culturelles entre le maroc et l'Espagne dan sl'Antiquité". A. Akerraz, P. Ruggeri, A. Siraj y C. Vismara (Eds.), L'Africa romana. XVI Convengo Internazionale: Mobilità delle persone e dei popoli, dinamiche migratorie, emigrazionie dimmigrazioni nelle province occidentali dell'Impero romano (Rabat, 2004), vol. 4, Carocci editore, 1326-1336. Roma.

PÉREZ GIRÓN, A. (2008): La colonia de Puente Mayorga. Ayuntamiento de San Roque, Cádiz.

PRESEDO VELO, F., MUÑIZ COELLO, J., SANTERO SANTURINO, J. M ${ }^{\mathrm{a}}$. y CHAVES TRISTÁN, F. (1982): Carteia I. Excavaciones Arqueológicas en España 120. Ministerio de Cultura, Madrid.

PRADOS MARTÍNEZ, F. (2011), "Los primeros pasos de la arqueología púnica en España y las excavaciones en Carteia". En L. Roldán y J. Blánquez (Eds. Cients.), Carteia III. Memorial. Junta de Andalucía, Universidad Autónoma de Madrid y CEPSA, 319-335. Madrid.

ROLDÁN GÓMEZ, L. (2009): "Esculturas romanas de Carteia (San Roque, Cádiz). Las excavaciones de Julio Martínez Santa-Olalla en los años 50". En T. Nogales e I. Roda (Eds.), IX Coloquio Internacional de Arte Romano Provincial. Roma y las provincias: modelo y difusión, L’Erma di Bretschneider Ed., 605-616. Roma.

ROLDÁN GÓMEZ, L., BENDALA, M., BLÁNQUEZ, J. y MARTÍNEZ, S. (Coords.), (2006): Estudio histórico-arqueológico de la ciudad de Carteia (San Roque, Cádiz). 1994-1999 (2 vols. y CD). Serie Arqueología Monografías. Memorias 24. Junta de Andalucía y Universidad Autónoma de Madrid, Madrid.

ROLDÁN GÓMEZ, L. y BLÁNQUEZ PÉREZ, J. (2011a): "Julio Martínez Santa-Olalla, una biografía pendiente (1905-1972)”. En L. Roldán y J. Blánquez (Eds. Cients.), Carteia III. Memorial. Junta de Andalucía, Universidad Autónoma de Madrid y CEPSA, 95-110. Madrid.

ROLDÁN GÓMEZ, L. y BLÁNQUEZ PÉREZ, J. (2011b): "Las excavaciones en Carteia en la década de los años 50: Julio Martínez Santa-Olalla (1952-1961)”. En L. Roldán y J. Blánquez (Eds. Ctfcos.), Carteia III. Memorial. Junta de Andalucía, Universidad Autónoma de Madrid y CEPSA, 111-134. Madrid.

ROLDÁN GÓMEZ, L. Y BLÁNQUEZ PÉREZ, J. (Eds. Cients.) (2012): Julio Martínez Santa-Olalla y el descubrimiento arqueológico de Carteia (1953-1961). UAM Ediciones y CEPSA Madrid. 
RODRÍGUEZ OLIVA, P. (2001): "Las últimas importaciones de sarcófagos paganos de talleres romanos en la Provincia Baetica". En N. Celdrán, J.M. y C. Guerri, E. (Eds.), El sarcófago romano. Contribuciones al estudio de su tipología, iconografía y centros de producción. Universidad de Murcia, 107-128. Murcia.

ROMERO DE TORRES, E. (1909):"Las ruinas de Carteya". Boletín de la Real Academia de la Historia, Tomo 54, 247-254.

ROMERO DE TORRES, E. (1934): Catálogo Monumental de España. Provincia de Cádiz (1908-1909). Ministerio de Instrucción Pública y Bellas Artes. Madrid (2 vols.).
VALVERDE DE CASAS, L. (1849): Carta histórica y situación geográfica de la ciudad de San Roque y términos de su demarcación en el Campo de Gibraltar. Escrita por D. Lorenzo Valverde natural de la misma, textos recopilados y anotados por F. y E. Cano Villalta (transcripción de E. Cano Villalta). Instituto de Estudios Campogibraltareños, Serie Historia 22, 2003. Cádiz.

WOODS, D. E.; COLLANTES DE TERÁN, F. y FERNÁNDEZ-CHICARRO, C. (1967): Carteia. Excavaciones Arqueológicas en España 58. Ministerio de Cultura, Madrid. 
